\title{
“Agora ou nunca! " - O imperador Guilherme II e a Primeira Guerra Mundial
}

\author{
Wolfgang Döpcke ${ }^{1}$ \\ Professor no Departamento de História \\ Universidade de Brasília - UnB
}

\begin{abstract}
Como citar este artigo:DÖPCKE, W. “Agora ou nunca!” - O imperador Guilherme II e a Primeira Guerra Mundial", Intelligere, Revista de História Intelectual, $\mathrm{n}^{\circ} 10$, pp. 206-243. 2020. Disponível em $<$ http://revistas.usp.br/revistaintelligere $>$. Acesso em dd/mm/aaaa-
\end{abstract}

Resumo: Este artigo discute o papel do Imperador Guilherme II da Alemanha, e sua responsabilidade pessoal na eclosão da Primeira Guerra Mundial. A primeira parte dedica-se à representação da polêmica personalidade do Kaiser, que, já na época, foi caracterizado como "psicopata imperial" e "césar megalomaníaco". Porém, ficará claro que, nas grandes crises internacionais antes de 1914, o Imperador se revelou menos belicista do que o esperado com base nessa sua imagem. Foi na Crise de Julho (1914) que a personalidade de Guilherme II impactou realmente a história mundial. Em dois momentos-chaves da Crise de Julho, a postura do Kaiser contribuiu de forma fundamental para colocar a Alemanha no caminho da confrontação armada. No dia 5 de julho, espontaneamente e em um surto de megalomania autocrática, ele sancionou a guerra austro-sérvia e, em seguida, pressionou o seu aliado austríaco a logo pegar em armas. Nessa ocasião, foi dominado por sua marcialidade, seu militarismo e seu autoritarismo, bem como pelo lado impulsivo e imprevisível de seu caráter. Quando a guerra contra a Rússia se tornou uma possibilidade real, ele ficou atemorizado e apresentou seu "plano pela paz". Nesse segundo momento, porém, quando tinha ainda o destino de paz ou guerra em suas mãos, fracassou, e mostrou o outro lado da sua

\footnotetext{
${ }^{1}$ Professor Associado em História Contemporânea no Departamento de História da Universidade de Brasília. Este ensaio é produto de um projeto de tradução de fontes primárias sobre a Primeira Guerra Mundial no qual participam também Theo Harden e Patrícia Rasche. Pela indispensável ajuda com a língua portuguesa agradeço a Olinta Pereira Teixeira Döpcke e ao Estevão de Rezende Martins.
} 
personalidade: a insegurança, a falta de coragem e liderança e a susceptibilidade a pressões e manipulações por terceiros. Rapidamente o Imperador se entregou às manipulações do seu chanceler e ao boicote austríaco de sua proposta. No final, rendeu-se ao cálculo da dinâmica das necessidades militares, defendido pelos seus generais. Conclui-se que, embora o Kaiser não quisesse a "grande guerra", sua responsabilidade em colocar a Alemanha a caminho desse confronto foi imensa.

Palavras-chave: Primeira Guerra Mundial; Alemanha; Guilherme II; Crise de Julho de 1914

\section{"Now or never!" - Emperor William II and World War}

Abstract: This article discusses the role of Emperor William II and his personal responsibility in the outbreak of the First World War. The first part is dedicated to the representation of the controversial personality of the Kaiser, who at the time was already characterized as "imperial psychopath" and "megalomaniac caesar". However, it is shown that in the great international crises before 1914, the Emperor proved to be less warmongering, contrary than his public image would have expected. It was in the July Crisis (1914) when William II's personality had an impact on world history. At two key moments in the July Crisis, the Kaiser's stance made a fundamental contribution to putting Germany on the road to armed confrontation. On $5^{\text {th }}$ of July, spontaneously, in an outbreak of autocratic megalomania, he sanctioned the Austro-Serbian war and then pressed his Austrian ally to soon take up arms. At this occasion, he was overwhelmed by his militarism and authoritarianism, as well as by the impulsiveness and the unpredictability of his character. When the war against Russia proved to be a real possibility, he became terrified and presented his "plan for peace". At this second moment, however, when he still had the alternative of peace or war in his hands, he failed and showed the other side of his personality: insecurity, lack of courage and leadership, and his susceptibility to pressure and manipulation by others. He quickly gave in to his Chancellor's manipulations and the Austrian boycott of his proposal. In the end, he surrendered to the calculation of the dynamics of military needs, defended by the military. In conclusion, it is shown that, although the Kaiser did not desire the "great war", his responsibility for putting Germany on the road to this war had been immense.

Keywords: World War I; Germany; William II; July 1914 Crisis 


\section{Introdução}

Um debate bizarro, porém bastante revelador dos tempos nos quais vivemos, permeia atualmente a mídia alemã e ocupa, ao mesmo tempo, os historiadores e os tribunais: os descendentes do ex-imperador Guilherme II lutam perante a justiça alemã por indenizações e pela devolução do patrimônio que lhes foi expropriado, depois de 1945, pela administração militar soviética na zona de ocupação da Alemanha Oriental. O Governo Federal e o Estado de Brandenburgo negam aos Hohenzollern a concessão destas indenizações, afirmando que os membros da família, principalmente o ex-herdeiro do trono, teriam apoiado significativamente o regime nacional-socialista e, assim, contribuído para a tomada e consolidação do seu poder. Os indícios de tal apoio são muitos e evidentes: não se duvida, dentre os historiadores especialistas na época nacional-socialista, do significado da sua contribuição, bem com daquela da classe aristocrática como um todo, para a derrubada da República de Weimar e a construção da aceitação e legitimação do regime nazista nos seus primeiros anos, junto aos quadros do conservadorismo mais tradicional, apesar de todos os mitos e lendas de resistência, fabricados depois de 1945.(MALINOWSKY, 2003); (URBACH，2016); (URBACH，2019); (HERBERT, 2019).

Portanto, esta briga jurídica e o concomitante debate tratam apenas superficialmente da questão quanto ao seu valor material. Porém, a rigor, trata-se de uma apreciação específica do passado recente, de mais uma batalha no campo da política de memória, com o objetivo em minimizar o apoio de que usufruíram os nazistas e de livrar as elites tradicionais guilherminas da acusação de colaboração na destruição da república democrática e da ascensão do regime hitlerista. Nesta disputa sobre o significado do passado, a limpeza da imagem dos Hohenzollern possui valor simbólico abrangente.

Opor-se a esta reviravolta conservadora na política de memória parece bem apropriado. Contudo, a reflexão sobre o desastroso papel que os Hohenzollern assumiram na história da Alemanha nos leva diretamente ao 
acontecimento que, antes de tudo, tornou possível a ascensão e vitória do regime nazista: a Primeira Guerra Mundial. A apreciação do papel da Casa Imperial na história da Alemanha e sua contribuição para a época das catástrofes necessariamente deve se focalizar naquela Guerra.

Qual foi o papel do Imperador Guilherme II na eclosão da “catástrofe primordial” da humanidade em 1914? Qual foi sua responsabilidade pessoal pelo caminho para a guerra que Alemanha seguia na chamada Crise de Julho de 1914, naqueles 31 dias nos quais o assassinato do Arquiduque austríaco Francisco Ferdinando se transformou, inicialmente em guerra continental e, depois, em guerra mundial?

Levantar a questão da responsabilidade pessoal não é considerado um exercício epistemologicamente anacrônico que poderia rebaixar a história para o abismo das "ações dos grandes homens" e da subjetividade moralizante retroativa. É uma questão legítima para o historiador, uma vez que "war was not inevitable. It was the choices that men made during those fateful days that plunged the world into a war. [...] Real people, actual flesh-and-blood human beings, were responsible for the tragedy of 1914 - not unseen, barely understood forces beyond their control."(MARTEL, 2014, pp. 420-1) Essa perspectiva, no entanto, apresenta-se obviamente insuficiente para o entendimento da eclosão da Guerra em si. Notadamente, tal análise deve se basear em contextos maiores de cultura, política e sociedade, e deve contextualizar a agência individual frente às causas mais profundas de curto e de longo prazo. Porém, representa um olhar específico, insuficiente embora necessário, para entender melhor o caminho para a guerra, escolhido pela Alemanha na chamada Crise de Julho.

Que tipo de pessoa era o Kaiser? Já na sua época, Guilherme II era uma figura altamente polêmica. De um lado, era idolatrado por, pelo menos, boa parte da aristocracia, da classe média e da burguesia: eles "aplaudiam o psicopata imperial", como escreveu Kantorowicz. (KANTOROWICZ, 1967, p.387) ${ }^{2}$ De outro lado, foi estigmatizado como um "césar megalomânico": autoritário, arrogante, egocêntrico, pomposo e teatral,

\footnotetext{
2 A publicação da sua investigação sobre a questão da culpa pela guerra, que implicou principalmente a Alemanha como instigadora do conflito, foi impedida em 1927. O trabalho foi redescoberto e publicado por Imanuel Geiss em 1967.
} 
ostentoso, vaidoso, facilmente irritável, agressivo e raivoso, porém carregado pela convicção da escolha divina. Seus ataques de raiva e seu comportamento insultante e humilhante eram legendários e não excluíam outros soberanos ou seus próprios generais. Sua natureza volátil e seu caráter instável, sua falta de tato, de bom senso e serenidade, e suas ideias absurdas e grotescas espantavam seus conselheiros e os observadores alemães e estrangeiros (RöHL,1989). Os seus contemporâneos, muito menos o seu entourage e círculo interno, não o pouparam com apelidos. Guilherme, o abrupto e brusco (Wilhelm der Plötzlliche), Guilherme o instável (Wilhelm der Unstebte), Guilherme, o apressado (Wilhelm der Eilige), mas também Guilherme, o tímido: ainda eram os apelidos mais simpáticos, mas já apontavam para certas caraterísticas da sua personalidade. Especialmente, o instável e o abrupto na sua personalidade chamou a atenção dos seus contemporâneos, que atribuíram estas propriedades do seu caráter a certas doenças como a neurastenia (fraqueza dos nervos), uma espécie de síndrome burn-out ou depressão crônica muito popular na virada do século (BRUNS; KARENBERG, 2019). Segundo Kantorowitz, ele era um Periodiker, no qual estados de euforia se alternavam com períodos de depressão. A sua desarmonia interna, seu ziguezague de ideias, suas reviravoltas abruptas entre audácia e temor, entre otimismo exagerado e pessimismo igualmente exagerado, entre a sensação de poder e a de impotência, seriam consequências desta doença. (KANTOROWITZ, 1967, p. 389) Para muitos, a sua megalomania somente ocultava as fraquezas da sua personalidade. Atrás de sua pomposidade, da sua marcialidade e do seu militarismo, poderia ser encontrado um Bramarbas, um ser medroso que procurava compensar seus profundos sentimentos de insuficiência, de carência e de inferioridade com uma performance pública de dramatização superficial. Até seu ex-chanceler Bernard von Bülow lhe atesta uma espécie de pacifismo por fraqueza, afirmando que ele "não queria a guerra, ele a temia [...] porque não confiava que seus nervos aguentassem o estresse de qualquer situação crítica."(PRINCE VON BÜLOW,1931, p.149)

Os historiadores e psicólogos atribuem esta mente perturbada do Imperador a vários acontecimentos nos seus primeiros anos de vida. No início, teria sido em função das complicações no seu nascimento, que ele por pouco não sobreviveu. Estas complicações teriam causado um leve dano ao 
seu cérebro, bem como a mutilação do seu braço esquerdo. Juntam-se ainda a rejeição do Guilherme aleijado pela mãe, que temia que ele seria "covarde" e nunca viria a ser "masculino" e o tratamento terrivelmente desumano para "corrigir" a mutilação do braço. Também teriam contribuído a falta de amor paterno e materno em geral, especialmente pela mãe "inglesa" Vitória, filha da Rainha Vitória, a rejeição pelos seus parentes ingleses e, finalmente, o peso insuportável dos ancestrais gloriosos nos seus ombros. Mais adiante será mostrado, como em dois momentos chaves da Crise de Julho, a personalidade do Kaiser, caracterizada por bruscas alternâncias entre megalomania e fraqueza, impactou os eventos e influenciou a postura do Imperador nas decisões fatídicas que levaram a Alemanha à Guerra.

Guilherme foi belicista durante todo o seu reinado? É bem possível destacar a contribuição do Kaiser para a política externa alemã de confrontação com as outras potências europeias e para a criação da imagem da Alemanha como potência agressiva e militarista. Ele criou e cultivou sua própria imagem como militarista. As suas intervenções políticas, espontâneas ou não, acarretavam dúvidas sobre a Alemanha como potência previsível e pacífica. Por exemplo, com o chamado "Telegrama Kruger” de 1896, seu famoso "discurso dos hunos", na ocasião da despedida em Bremerhaven, no dia 27 de julho de 1900, e através da chamada Política Mundial (Weltpolitik), iniciada em 1897/8 juntamente com a aceleração do armamento marítimo, bem como no "Escândalo do Daily Telegraph" de 1908, Guilherme criou e agravou um duradouro antagonismo com a Grã-Bretanha. Por último, no chamado "Kriegsrat" (Conselho de Guerra) do dia 8 de dezembro de 1914, mostrou também um belicismo até então desconhecido, embora sem consequências políticas concretas.

De outro lado, e mais importante: ao contrário destas demonstrações verbais de belicismo e de confrontação, nas principais grandes crises da política europeia antes de 1914, o Kaiser mostrou cautela e moderação surpreendentes. Nas duas crises do Marrocos (1905 e 1911), Guilherme não foi o principal instigador da confrontação pelo lado alemão. $\mathrm{Na}$ primeira destas crises, ele claramente se opôs ao conflito e à guerra, que alguns de seus militares desejavam. (GUTSCHE, 1991, p.123) Já na Segunda Crise do 
Marrocos (1911), embora muito hesitante, reservado e incrédulo, ele sancionou a agressiva estratégia alemã, inventada pelo Secretário das Relações Exteriores. O Kaiser não foi, contudo, a força motriz deste segundo confronto com a França. Ele de forma alguma estava cogitando a guerra que os ultranacionalistas pangermânicos ruidosamente exigiam. Quando a Alemanha foi obrigada a recuar de sua postura agressiva, depois de um pronunciamento de Lloyd George no dia 21 de julho de 1911, Guilherme sofreu a raiva dos ultranacionalistas alemães e, ainda mais, ganhou dois novos apelidos, um pelos franceses: "Guillaume le timide", e outro, como crítica, dos pangermânicos: "Guilherme o pacífico". 3

$\mathrm{Na}$ primeira crise balcânica em 1908 (a crise da anexação da Bósnia), o papel de Guilherme foi, mais uma vez, bastante reduzido. Ele endossou a política do seu chanceler, muito contra sua própria vontade, mas não foi um dos principais instigadores da estratégia conflituosa e não mostrou uma postura expressivamente belicista. Quando eclodiu a Primeira Guerra Balcânica (1912) e a Áustria desejava uma guerra contra a Sérvia, a postura do Kaiser e da sua liderança política tinham sido muito claras: a paz europeia deveria ser preservada e a Alemanha não queria, de jeito algum, uma guerra que envolvesse a Rússia. Categoricamente, Guilherme ordenou comunicar a Viena: "Declarei expressamente [ao Chanceler] que, por causa da Albânia e do Durazzo, eu, em circunstância alguma, marcharei contra Paris e Moscou." Já na Segunda Guerra Balcânica, a liderança política da Alemanha concedeu certo "apoio moral" ao ultimato austríaco, para que a Sérvia se retirasse da Albânia. Isto aconteceu sem consulta ao Kaiser, mas este retroativamente endossou tal decisão, mas ainda privilegiou uma solução conjunta das grandes potências. ${ }^{5}$ Nesta ocasião, ele estava também determinado a evitar um conflito com a

\footnotetext{
${ }^{3}$ Para as pressões ultranacionalistas sob Guilherme, e suas críticas ao Kaiser como "Guilherme o pacífico", ver, entre outros: GP vol. 29, Nr. 10699, Der Rat im kaiserlichen Gefolge an AA, 9.8.1911. GP - Die Große Politik der europäischen Kabinette 1871-1914. Sammlung der Diplomatischen Akten des Auswärtigen Amtes. Im Auftrag des Auswärtigen Amts, Berlin 1922-1927.

${ }^{4}$ GP vol. 33, Nr. 12348, Kaiser Wilhelm an AA, 9.11.1912. O chanceler reforçou esta rejeição de um ataque austríaco e seu apelo à diplomacia, contra a Sérvia, com palavras muito duras, raramente ouvidas na correspondência diplomática, junto ao seu aliado: Ibid., Nr. 12819, Bethmann-Hollweg an Berchtold, 10.2.1913.

${ }^{5}$ Ibid. Nr. 14161, Zimmermann an Wedel, 16.10.1913. Ibid, Nr. 14162, Zimmermann an Tschirschky, 16.10.1913. Ibid. Nr. 14172, Wedel an AA, 17.10.1913. Ibid. Nr. 14174, Zimmermann an Waldthausen, 18.10.1913.
} 
Rússia e até se opôs ao belicismo austríaco e a seus projetos territoriais nos Bálcãs.

Ainda em abril de 1914, dois meses antes de conceder carta branca, Guilherme aconselhou os austríacos a procurarem um modus vivendi com a Sérvia. ${ }^{6}$ Ele permaneceu assim como um dos grandes obstáculos para a conflagração de uma guerra, fato muito lamentado pelos belicistas, tanto na Alemanha quanto na Áustria. Em uma conversa no dia 16 de março de 1914, entre o Chefe do Estado Maior da Áustria e Tschirschky, embaixador alemão em Viena, quando o General Conrad pressionou por uma guerra contra a Rússia, o embaixador respondeu: "Existem duas pessoas importantes que são contra [esta guerra]: seu Arquiduque Francisco Ferdinando e meu Kaiser.” (CONRAD,1922, p.597). Por isto, tanto mais surpreende o fato de que Guilherme, no dia 5 de julho, numa decisão solitária e espontânea, deu luz verde à Áustria para atacar seu vizinho sérvio, assumindo o risco de uma intervenção russa. Sua postura antes de julho de 1914, especialmente a rejeição de qualquer guerra nos conflitos balcânicos, não levava a esperar tal concessão.

\section{Guilherme II e a "Carta Branca": “Agora ou nunca"}

Guilherme II recebeu a notícia do assassinato do herdeiro ao trono austro-húngaro, Arquiduque Francisco Ferdinando, e de sua esposa, na tarde do dia 28 de junho, a bordo de seu iate Meteor, quando participava de uma regata na Semana de Kiel. Ele se sentiu afetado profundamente pela morte dos dois, pois considerava a vítima Francisco Ferdinando um amigo, com o qual cultivou relações políticas e pessoais especiais. Mas também tomou pessoalmente o ataque ao "princípio monarquista", que entreviu por detrás do atentado. (RÖHL,2014,p.1016);( MCMEEKIN,2014,I,4) Ele retornou imediatamente para Berlim, mas permitiu que a regata concluísse seu trajeto. O espírito (ainda) era pacífico, e nada indica que Guilherme, ou a liderança política alemã, consideravam o assassinato inicialmente como uma boa oportunidade e justificativa para uma guerra austríaca contra a Sérvia. Tampouco Guilherme pensava em guerra a esta altura que ele discutiu, ainda no dia 3 de julho, numa audiência com o adido militar romeno, os detalhes de

\footnotetext{
${ }^{6}$ Ibid. Nr. 15541, Bethmann Hollweg an Tschirschky, 6. 4. 1914, citado de um telegrama do
} Kaiser. 
uma viagem a Bucareste, planejada para outono. (RÖHL, 2014, p. 1017) ${ }^{7}$

Berlim estava em plenas férias e Guilherme lá encontrou poucos membros do seu círculo íntimo de poder. O chanceler Bethmann Hollweg, o Chefe do Estado Maior, Helmuth von Moltke, o Almirante Tirpitz e o Secretário do Estado do Exterior Gottlieb von Jagow estavam ausentes. Bethmann Hollweg passava as férias na sua residência de campo em Hohenfinow, perto de Berlim, e foi frequentemente à capital nos dias depois do atentado. Guilherme retomou suas rotinas reais, e encontrou, nestas ocasiões, alguns dos seus principais assessores. Porém, não houve um encontro para explicitamente discutir as repercussões políticas do assassinato e uma possível estratégia alemã frente ao desafio que seu aliado austríaco estava enfrentando. Também não existem, como Röhl especula, indícios de uma tomada coletiva de decisão em prol de uma linha dura, i.e de tirar proveito daquele assassinato para provocar uma guerra austro-sérvia. (RÖHL,2014, pp. 1016-21)

Pelo contrário, os primeiros (porém tímidos e fragmentados) sinais de orientação que a Secretaria das Relações Exteriores (Auswärtiges Amt AA), representada pelo subsecretário Zimmermann na ausência do secretário von Jagow, deu à Áustria, eram também de moderação e cautela. Numa reunião com o Ministro da Relações Exteriores da Áustria, Conde Berchthold, no dia 30 de junho, o embaixador alemão, Heinrich von Tschirschky, alertou “contra passos precipitados". ${ }^{8}$ Numa audiência com o imperador Francisco José no dia 2 de julho, Tschirschky, embora afirmando, de maneira genérica, o apoio que Guilherme II daria para uma "decisão firme" da Áustria, recomendava uma reação "bem pensada", no sentido de considerar a situação

\footnotetext{
${ }^{7}$ O relatório do Plenipotenciário Militar da Saxônia em Berlim, do dia 3 de julho, o do Enviado da Saxônia em Berlim (2 de julho), bem como o do Enviado da Baviera (4 de julho) confirmam também esta postura inicialmente pacífica do Imperador. Ver: Leuckart para Carlowitz. Bericht No. 73/3472, 3.7.1914, reproduzido em Geiss I, p. 73. Salza Lichtenau an Vitzthum. Bericht No. 1045, 2..7.1914. Geiss, I, p. 71. Lerchenfeld (enviado da Bavária). Bericht 328, 4.7.1914. Bayrische Dokumente zum Kriegsausbruch und zum Versailler Schuldspruch. Munique \& Berlim 1922, p. 113. Geiss I e II - Geiss, Imanuel (ed.), Julikrise und Kriegsausbruch 1914. Eine Dokumentensammlung, 2 vols. Hannover 1963/64.

${ }^{8}$ DD 7. Der Botschafter in Wien an den Reichskanzler, 30.6.1914. Die Deutschen Dokumente zum Kriegsausbruch 1914. Kautsky, K. (Hrg); Vollständige Sammlung der von Karl Kautsky zusammengestellten amtlichen Aktenstücke mit einigen Ergänzungen. Im Auftrag des Auswärtigen Amtes nach gemeinsamer Durchsicht mit Karl Kautsky hrsg. von Graf Max Montgelas und Walter Schücking. 4 vols., Charlottenburg 1919.
} 
política europeia e possíveis reações das outras potências. ${ }^{9}$ O subsecretário Zimmermann dava a entender, em conversas com os embaixadores russo e britânico em Berlim, que ele rejeitava a acusação de um complô por parte do Estado da Sérvia, e recomendou uma minuciosa investigação para descobrir os perpetradores. ${ }^{10}$ Ainda no dia 4 de julho, Zimmermann aconselhou o embaixador austríaco a agir com grande cautela e a não apresentar exigências humilhantes à Sérvia. ${ }^{11}$

No entanto, os conselhos de cautela não foram os únicos sinais que Viena recebeu de Berlim nestes primeiros dias depois do atentado. No dia 1 de julho, Alexander Hoyos, o Chefe de Gabinete do Ministro das Relações Exteriores da Áustria e um falcão convicto no governo austríaco, teve uma conversa informal com o jornalista alemão Victor Naumann. Nesta conversa, Nauman, amigo de confiança do Diretor Político do Auswärtiges Amt da Alemanha, von Stumm, revelou a crescente disposição, não somente entre os militares alemães, mas também no $\mathrm{AA}$, de arriscar a possibilidade de uma guerra preventiva contra a Rússia. No que concerne a Sérvia, Naumann pensava que no Ministério se considerava aquele momento como uma boa oportunidade para "provocar a grande decisão" e que Guilherme II, quando fosse abordado de maneira certa, apelando ao "princípio monarquista", certamente daria seu apoio. ${ }^{12}$

O significado desta visita de Naumann e a origem das posições referidas permanecem enigmáticos. O próprio Hoyos, nas mútuas recriminações entre a Áustria e Alemanha depois da Guerra, alegou que tinha sido esta conversa que o fez acreditar que o pedido à Alemanha de apoio incondicional a uma guerra, envolvendo até a Rússia, teria uma receptividade positiva em Berlim. (ALBERTINI,1953, v.2, p. 135) Igualmente, para Fischer e

\footnotetext{
${ }^{9}$ DD 11. Der Botschafter in Wien an den Reichskanzler, 4.7.1914.

${ }^{10}$ BD 22. Sir H. Rombold to Sir Edward Grey, 30.6.1914. British Documents on the Origins of the War, 1898-1914. Vol. XI: The Outbreak of War: Foreign Office Documents. Ed. G.P. Gooch \& Harold Temperley. London 1926. Lerchenfeld (enviado da Bavária). Bericht 364, 2.7.1914. Bayrische Dokumente zum Kriegsausbruch. Swerbejew an Sasonow, 2.7.1914. repri, em: Geiss, I, p. 60-2.

${ }^{11}$ ÖD I, 5. Graf Szögyény an Grafen Berchtold, 4. Juli 1914. Die Österreichisch-Ungarischen Dokumente zum Kriegsausbruch. Hrsg. vom Staatsamt für Äußeres in Wien (Berlin: NationalVerlag), 1923.

${ }^{12}$ Aufzeichnung Hoyos' über Unterredung mit Victor Naumann. Viena, 1.7.1914. ÖD 9966, repri, em: Geiss I, p. 72-3. Ver também: Albertini, L. The Origins of the War of 1914, vol. 2, pp. 129.
} 
seus discípulos, esta conversa serve como prova de que, desde o início, a Alemanha teria empurrado a Áustria para a guerra. De outro lado, trata-se de uma conversa informal com um jornalista, embora com contatos diretos na cúpula do AA. Ademais, as ideias referidas por Naumann refletiam mais a posição dos militares alemães e contrariaram a posição oficial do Secretariado. ${ }^{13}$

O Kaiser estava inicialmente em disposição mais pacífica mas, em algum momento nestes primeiros dias depois do atentado, aconteceu uma reviravolta. Talvez o cancelamento de sua participação no enterro do Arquiduque, por causa de um alerta sobre um atentado, supostamente planejado por sérvios, contra a pessoa do Kaiser, tenha provocado esta mudança de postura. ${ }^{14}$ No dia 3 ou 4 de julho, ele tomou conhecimento do ofício do Embaixador Tschirschky, no qual este relatava seus avisos de cautela dados a Viena. Furioso, o Kaiser atulhou este documento com seus mal afamados comentários marginais e o devolveu para o AA no dia 4 de julho. Censurando a postura cautelosa do Tschirschky como "bobagem" e "estupidez", e como tendo sido assumida sem autorização, o Imperador exclamou que a Áustria deveria acertar as contas com a Sérvia "agora ou nunca", com medidas muito "severas" (original: "Mit den Serben muss aufgeräumt werden, und zwar bald'). Este abafo do Kaiser teria iniciado uma reviravolta na política alemã sobre a questão de uma guerra austro-sérvia? A partir deste momento, no dia 4 de julho, quando o Kaiser devolveu o ofício com as suas notas marginais para o AA, a Alemanha teria recomendado uma guerra entre a Áustria e a Sérvia? Muitos historiadores dizem que sim! Para Fischer, Geiss e Gutsche, foram estas notas marginais, compreendidas no AA como uma ordem, que iniciaram a volte-face na política alemã. Esta, segundo Fischer, "mais grave decisão" do Imperador na Crise de Julho, foi tomada ciente de que as "medidas severas" poderiam provocar uma intervenção russa e uma guerra germano-russa. (FISCHER, 1961, p.279); (GEISS I,1963, p.79); (GUTSCHE, 1991, p.157).

Será que um comentário marginal do Kaiser realmente "teve impacto sobre a história mundial", como supõe Hermann Kantorowicz?

\footnotetext{
${ }^{13}$ Ver: Salza Lichtenau an Vitzthum. Bericht No. 1045, 2..7.1914. Geiss I, p. 71.

${ }^{14}$ DD Nr. 6a. Der Generalkonsul in Sarajevo an das Auswärtige Amt, 1. Juli 1914. DD Nr. 6b. Der Reichskanzler an den Botschafter in Wien, 2. Juli 1914.
} 
(KANTOROWICZ,1967, p. 87). Talvez sim, porém certas reservas parecem apropriadas. Em primeiro lugar, as anotações marginais não eram belicistas per se. O Kaiser também achou como um "truísmo" considerar, antes de optar por "medidas severas", a situação internacional, i.e, neste caso, principalmente a possível reação russa. Segundo, as suas legendárias notas marginais na correspondência diplomática raramente influenciaram diretamente a direção da política alemã e não eram uma ordem. Terceiro, ainda não é explicado como a nova postura mais belicista do Kaiser teria sido comunicada. Não existe nenhum documento mostrando, por exemplo, a transmissão das novas “ordens" para o embaixador em Viena. Especula-se que teria sido por telefone, sem nenhum traço na documentação diplomática, de que acontecera tal transmissão. (KANTOROWICZ,1967, p. 87); (GUTSCHE, 1991, pp.157-8). Elas surtiram um certo efeito, no entanto alguns dias mais tarde. Contava-se nos círculos do AA que Tschirschky teria recebido uma reprimenda oficial por sua "tibieza” junto ao Ministro das Relações Exteriores da Áustria. ${ }^{15}$

De qualquer modo, no mesmo dia em que Guilherme II devolveu o ofício do Tschirschky para o AA, o embaixador já iniciara decididamente a reviravolta que, aliás, correspondia muito mais às suas próprias convicções belicistas e pró-austríacas. ${ }^{16}$ Ele convocou o jornalista Ganz, correspondente vienense do jornal "Frankfurter Zeitung”, e enfatizou na entrevista que agora “o Kaiser e o Império" iriam apoiar a Áustria incondicionalmente em qualquer ação contra a Sérvia. Se a Áustria agisse o mais rápido possível, melhor. Tschirschky instruiu o jornalista a comunicar esta nova política imediatamente ao Ministério das Relações Exteriores em Viena. ${ }^{17}$

\footnotetext{
${ }^{15} \mathrm{O}$ embaixador alemão em Londres, Max von Lichnowsky, que passou o dia 5 de julho em Berlim, recordou tal reprimenda. Lichnowsky, Karl Max. My Mission to London, 1912-1914. Nova Iorque e Londres 1918. Pouco tempo mais tarde, também o embaixador austríaco em Berlim, Conte Szögyény-Marich, ouviu falar desta censura. Tel. Nr. 243. Szögyény an Berchthold, 8.7.1914, em: Geiss 1, p. 125.

${ }^{16}$ Para o embaixador Heinrich, Freiherr von Tschirschky und Bögendorff, uma figura chave na Crise do Julho, e sua política belicista e de "intrigas", e seu papel intrigante em torno do dia 29 de julho, ver: Meyer-Arndt, Lüder; Die Julikrise 1914. Wie Deutschland in den Ersten Weltkrieg stolperte. Köln, Weimar, Wien (Böhlau) 2006, pp. 10. Clark, Christopher. The Sleepwalkers: How Europe Went to War in 1914. Londres 2012. Otte, Thomas: July Crisis. The World's Descent into War, Summer 1914. Cambridge (Cambridge University Press) 2014, pp. 67. Albertini. Vol 2, cap. 1.

${ }^{17} \mathrm{Nr}$. 10038. S. Walterskirchen, G. Forgách. Tagesbericht über eine Unterredung mit dem Korrespondenten der "Frankfurter Zeitung", 4.7.1914, repr. em: Bittner, L.. ÖsterreichUngarns Aussenpolitik, Nendeln/Lichtenstein (Kraus) vol. VIII, 1930, p. 295.
} 
No entanto, a Áustria ainda estava longe de poder agir o mais rápido possível e se encontrava ainda no processo decisório, cujo resultado dependia exclusivamente da posição alemã. É certo que o assassinato fortaleceu o "partido de guerra", encabeçado pelo Chefe do Estado Maior, Conrad von Hötzendorf, e que desta vez o influente e até então cauteloso Ministro das Relações Exteriores, Conde Berchthold, também defendeu uma guerra contra a Sérvia. Mas não ocorria, como alguns historiadores supõem, que neste exato momento a Áustria-Hungria houvesse decidido em uníssono a favor desta guerra. (HAMILTON; HOLGER, 2005, p.67) O próprio Imperador Francisco José estava indeciso. Ainda mais importante, o Conde Tisza, o Primeiro Ministro do lado húngaro da Monarquia Dual, cuja aprovação de uma guerra era constitucionalmente indispensável, vigorosamente se opôs, como "calvinista" (considerando guerra em si como abominável) e como "magiar" (temendo o aumento da população eslava na Áustria, em caso de uma conquista da Sérvia), como colocou Luigi Albertini. (ALBERTINI, 1953, v2, p.127) ${ }^{18}$

Ao final, demorou até o dia 14 de julho para convencer Tisza de uma guerra contra a Sérvia, que ele aprovou ainda condicionando à resposta sérvia a um ultimato austríaco e à resolução de que, com a guerra, a Áustria não realizaria anexações territoriais em detrimento da Sérvia. ${ }^{19} \mathrm{O}$ voto alemão positivo foi decisivo nas pressões sobre Tisza. (ALBERTINI, 1953, v2,p.175) Mas este apoio foi também considerado essencial para proteger a Áustria contra um possível ataque da Rússia, como reiterou o Imperador Francisco José em uma conversa com Conrad von Hötzendorf. E Francisco José estava muito inseguro acerca da posição alemã ainda neste dia 5 de julho. ${ }^{20}$

Para assegurar a apoio alemão, o governo austríaco despachou um enviado especial, o conde Hoyos, diplomata e Chefe de Gabinete do ministro Berchthold, para Berlim. Ele estava munido de dois documentos: uma

\footnotetext{
${ }^{18}$ Estes documentos demonstram as posturas iniciais de Francisco José: ÖD I, 2. Vortrag des ungarischen Ministerpräsidenten Grafen Tisza (para o Imperador), 1. Juli 1914. Unterredung Berchthold - Conrad, 1.7.1914. Conrad. Aus meiner Dienstzeit, IV, repr. em Geiss I, p. 60.

${ }^{19}$ McMeekin, S. Juli 1914, cap. II,7. Albertini, vol. 2. ÖD, I, 12. Vortrag des ungarischen Ministerpräsidenten Grafen Tisza, 8. Juli 1914.

${ }^{20}$ Audienz Conrads bei Franz Joseph in Schönbrunn, 5.7.1914. Conrad. Aus meiner Dienstzeit, IV, repr. em Geiss I, p. 83. Ver também: Unterredung Berchthold - Conrad, 6.7.1914 :"Se a Alemanha concorda, a nossa Majestade [Franz Joseph] será a favor da guerra". Conrad. Aus meiner Dienstzeit, IV, repr. em Geiss I, p. 91.
} 
carta pessoal do Francisco José ao Kaiser Guilherme e um memorando, que tinha sido elaborado antes do assassinato e foi levemente modificado para esta ocasião (memorando Matscheko). ${ }^{21}$ Nenhum dos dois documentos falava em guerra. Especialmente o Memorando Matcheko, embora apresentando a situação austríaca depois da Segunda Guerra Balcânica nos termos mais sombrios possíveis, concluía por propostas meramente políticas e diplomáticas. No máximo, a carta de Francisco José desejava a "eliminação" da Sérvia dos Bálcãs "como fator de poder político". Porém, o Kaiser extraiu destes documentos (ou da comunicação verbal do embaixador austríaco - não se sabe) uma vontade austríaca inequívoca de guerra. Da apresentação destes dois documentos, numa audiência do Kaiser com o embaixador austríaco no dia 5 de julho, resultou a má-afamada "carta branca", que garantiu à Áustria apoio alemão incondicional em caso de uma guerra contra a Sérvia. Como isto poderia acontecer e qual foi o papel de Guilherme II neste episódio que tanto direcionou a Europa para uma guerra continental?

O conde Hoyos chegou na manhã do domingo, dia 5 de julho, em Berlim, instruiu primeiro o embaixador austríaco e depois conferiu com subsecretário Arthur Zimmermann, Chefe em exercício no AA, mesmo antes do embaixador austríaco ter a audiência com Guilherme II a uma hora da tarde. No encontro com Zimmermann, o conde Hoyos revelou o que seriam os planos austríacos: atacar a Sérvia logo sem aviso prévio, e, depois, realizar a partilha completa do país entre a Áustria, a Bulgária e a Albânia, mesmo correndo o risco de uma guerra contra a Rússia. Certamente, nada disto tinha sido decidido em Viena e, depois, frente a um furioso Tisza, Hoyos teve que se retratar e declarar estas ideias, apresentadas como se expressassem a política oficial da Áustria, como meramente pessoais. ${ }^{22}$ Ouvindo os supostos planos austríacos, Zimmermann teria exclamado que atacar a Sérvia resultaria "com probabilidade de 90\% em uma guerra europeia”, e Hoyos inclusive teria falado até em guerra mundial. Mas o subsecretário, representando seu chefe von Jagow nesta ocasião, sequer fez questão de informar o Kaiser, cuja reunião

\footnotetext{
${ }^{21}$ ÖD I, 1. Handschreiben Kaiser und König Franz Josephs an Kaiser Wilhelm, 2. Juli 1914. Beilage zu I, 1: Denkschrift zum Handschreiben Kaiser und König Franz Josephs an Kaiser Wilhelm, 2. Juli 1914.

${ }^{22}$ DD Nr. 18. Der Botschafter in Wien an das Auswärtige Amt, 7. Juli 1914. DD Nr. 61. Der Staatssekretär des Auswärtigen an den Botschafter in Wien, 17. Juli 1914.
} 
com o embaixador iria acontecer em seguida, sobre o que tinha sido apresentado como intenções concretas da Áustria. ${ }^{23}$

Em seguida, em torno de uma hora da tarde, o Kaiser recebeu o embaixador austríaco no seu palácio "Neues Palais" em Potsdam. ${ }^{24}$ Ele, depois de ler "cuidadosamente" os dois documentos austríacos, já interpretando a carta de Francisco José como decisão austríaca em prol de uma guerra, primeiro reagiu dentro da linha da abordagem cautelosa da política alemã até então, contrariando também seus próprios comentários belicistas no ofício do Tschirschky do dia anterior. Ele alertou sobre uma "possível complicação europeia" e não assumiu nenhum compromisso sem antes consultar seu chanceler. Depois do almoço, o embaixador Szögyény insistiu mais uma vez e conseguiu arrancar de Guilherme a desejada "carta branca". Mesmo se, em consequência de uma guerra austro-sérvia, a Rússia interviesse, o Kaiser declarou que a Alemanha "manterá sua lealdade habitual e ficará ao nosso lado". O ataque à Sérvia deveria acontecer rapidamente para se aproveitar da oportunidade de guerra a partir da comoção europeia quanto ao assassinato. Guilherme teria que consultar seu chanceler, mas estava convencido de sua anuência, restringindo acentuadamente o espaço de manobra de Bethmann Hollweg. Por último, numa espécie de exorcismo de sua própria coragem, Guilherme repetiu o mantra tranquilizador de que a Rússia ainda não estaria preparada para uma guerra.

Por que esta reviravolta de uma posição de cautela e moderação para uma que abriu o caminho para a "catástrofe primordial" durante a mesma reunião? Foi mais um exemplo da espontaneidade do Guilherme, o abrupto, e das suas alternâncias bruscas entre temor e audácia? Uma análise mais profunda deste encontro demonstra com clareza suas precariedades e limitações pessoais, bem como, ao mesmo tempo, as do seu regime sultanesco.

Primeiro, a disposição megalomaníaca do Imperador de decidir sozinho se manifesta no fato de que ele nem sequer se preparou para este encontro e não se reuniu antes com os seus conselheiros. $\mathrm{O}$ argumento,

\footnotetext{
${ }^{23}$ Sobre este encontro entre Hoyos e Zimmermann não existe uma ata oficial. No entanto, mediante uma ampla documentação indireta, consegue-se reconstruir seu conteúdo. Ver (entre outros): Otte, Thomas: July Crisis, p. 78-80.

${ }^{24}$ Deste memorável encontro somente existe uma ata bem resumida do embaixador. De fato ela muito provavelmente terá sido redigida por Hoyos, que não participou da audiência. ÖD I, 6. Graf Szögyény an Grafen Berchtold, 5. Juli 1914.
} 
formulado por alguns historiadores, de que ele já tinha se decidido por uma postura belicista, entregando-se às pressões (embora isoladas e fragmentadas) de alguns militares, não convence, porque ignora a reviravolta durante a reunião. ${ }^{25}$ Segundo, todo sistema de governo falhou profundamente. Os (poucos) membros da liderança política do Reich presentes em Berlim naquele momento (Zimmermann e Bethmann Hollweg), não instruíram o Kaiser antes da reunião. Zimmermann, ao ouvir os bizarros planos austríacos de extinguir a Sérvia como Estado, deveria ter informado o Kaiser imediatamente, uma vez que esta política certamente provocaria uma intervenção militar russa nos Bálcãs e nunca, nem mesmo nos momentos de maior postura agressiva, havia sido cogitada pelo governo alemão ou pelo Kaiser. Porém, como sublinha Meyer-Arndt, no sistema sultânico do Imperador, com toda a dependência do bem-querer do Imperador e da sua preferência por assessores subservientes, todos evitavam assumir responsabilidade e ninguém tinha coragem de dar ao Imperador conselhos não solicitados. (MEYER-ARNDT, 2006, P..26) O Imperador necessitava também de assessoria por perto durante a reunião. De início, ele aceitou, sem pedir uma prova material, a acusação austríaca de um envolvimento de órgãos do Estado da Sérvia no atentado. ${ }^{26}$ Além disto, Guilherme interpretou a solicitação austríaca, sem muita razão, como pedido de ajuda para uma guerra, embora os textos dos dois documentos também pudessem ser lidos como pedido de uma solução diplomática. Até o ultrabelicista Ministro da Guerra Falkenhayn, depois de ler os documentos, chegou à conclusão de que estes não expressavam uma decisão austríaca firme para uma guerra. ${ }^{27}$ Ademais, no caso de uma guerra austríaca de agressão, os

\footnotetext{
${ }^{25}$ Fischer, Fritz: Griff nach der Weltmacht. Die Kriegszielpolitik des Kaiserlichen Deutschlands. Düsseldorf 1961, p. 61. Krumeich, Juli 1914, p. 69. Ele também não sofreu influência dos militares. Ver: Mombauer, Annika. Helmuth von Moltke and the Origins of the First World War (2001). Afflerbach, Holger. Falkenhayn. Politisches Denken und Handeln im Kaiserreich, Munique 1994

${ }^{26}$ Vale relembrar que, neste momento, as próprias investigações austríacas, chefiadas pelo juiz Leo Pfeffer. andavam totalmente às escuras. O envolvimento da "Mão Negra", de Dragutin Dimitrijevis ("Apis"), chefe do serviço secreto militar, e o prévio conhecimento dos planos do atentado pela liderança política da Sérvia ainda eram desconhecidos. Ainda no dia 13 de julho, o Conselheiro von Wiesner comunicou ao Ministério das Relações Exteriores que "não está comprovado, ou somente se suspeita, que o governo sérvio tivesse conhecimento da preparação e da execução do atentado, como do fornecimento das armas utilizadas. Tudo indica que esta possibilidade pode ser descartada. ". ÖD I, 17. Sektionsrat von Wiesner an das k. u. k. Ministerium des Äußern, 13. Juli 1914.

${ }^{27}$ Falkenhayn an Moltke, 5.7.1914, rerpr. in: Geiss I, p. 86.
} 
termos da aliança austro-alemã não previam um apoio automático, ao contrário das afirmações do Kaiser. ${ }^{28}$

Terceiro, com a concessão de apoio incondicional, independente das ações concretas da Áustria-Hungria, o Kaiser deixou a iniciativa completamente nas mãos austríacas, renunciando qualquer influência sobre as suas decisões e tornou a Alemanha assim refém de seu parceiro na Tríplice Aliança. Quarto, tudo indica que Guilherme teria caído em uma armadilha austríaca bem arquitetada. $\mathrm{Na}$ exposição dos planos austríacos, tanto Hoyos quanto o embaixador Szögyény apresentaram as decisões austríacas como fato já consumado e omitiram a posição húngara de Tisza. O conhecimento da feroz oposição à guerra da outra metade da Monarquia Dual certamente teria influenciado a postura do Kaiser. Por último, alguns historiadores suspeitam que foi a habilidade de Szögyény, conhecendo muito bem os lados fracos do imperador alemão, de apelar à honra e ao cavalheirismo do Kaiser, bem como à sua relação pessoal com o Imperador Francisco José, que poderia ter feito com que Guilherme cedesse espontaneamente e formulasse suas decisões fatais. (MEYER-ARNDT, 2006, p. 27-8)

Depois da audiência, o Kaiser reuniu, separadamente, os seus principais conselheiros civis e militares presentes em Berlim, não com o objetivo de avaliar e discutir a política alemã frente ao dilema austríaco, mas somente para comunicar a decisão que tomara. Na reunião com o chanceler Bethmann-Hollweg ele também não pediu opinião para fundamentar sua decisão constitucionalmente, mas o forçou a concordar. ${ }^{29}$

Resumamos, pois, a postura do Kaiser nestes dois dias fatídicos. Guilherme concluiu que o antagonismo entre a Áustria e a Sérvia havia chegado a um ponto tal que "uma ação imediata [isto é uma guerra] seria a melhor e mais radical solução para nossos problemas nos Bálcãs", como relatou o embaixador austríaco no dia 6 de julho. ${ }^{30}$ Ele quis uma terceira guerra balcânica, desta vez entre a Áustria e a Sérvia, que certamente teria infligido uma derrota esmagadora à Sérvia, levando-se em conta o balanço do poder

\footnotetext{
${ }^{28}$ Anotação de Bethmann Hollweg sobre uma conversa com Szögyény no dia 6.7.1914, repri. in Geiss I, p. 95.

${ }^{29}$ Kantorowicz. Gutachten zur Kriegsschuldfrage, pp. 229: “A Coroa disse: 'eu ordeno, e os conselheiros respondem: 'A seu comando!'”[ou: “às suas ordens! ”]

${ }^{30}$ ÖD I,7. Graf Szögyény an Grafen Berchtold, 6. Juli 1914.
} 
militar e o esgotamento do exército sérvio depois de lutar em duas guerras recentes. Ele não queria uma guerra entre a Rússia e a Alemanha e não acreditava em uma intervenção militar russa para salvar a Sérvia da destruição. ${ }^{31}$ Nem a Rússia nem a França estariam preparadas para uma guerra e "o Czar nunca estaria ao lado dos assassinos de um príncipe". ${ }^{32}$ A Grã-Bretanha sequer foi mencionada. Os depoimentos dos militares presentes na reunião com o Kaiser no dia 5 de julho confirmam também este seu pressuposto. ${ }^{33}$ Até mesmo estes ardentes defensores de uma "guerra de prevenção" contra a Rússia não viam aquela como uma boa ocasião para tal guerra. Inclusive, não acreditavam na determinação austríaca de escalar o conflito até uma guerra e partiram para suas férias. ${ }^{34}$ Falkenhayn garantiu ao Chefe do Estado Maior, Moltke, que este podia tranquilamente continuar cuidando da sua saúde no spa de Karlsbad. ${ }^{35}$

Guilherme não possuía, contudo, absoluta certeza sobre a neutralidade russa. Ao Ministro da Guerra, Falkenhayn, ele perguntou se o exército estaria pronto para todas as eventualidades, a que o Ministro respondeu positivamente. Guilherme recusava, porém, quaisquer preparações concretas para tal situação. E, junto ao seu chanceler, insistiu que "nós deveríamos nos empenhar com todos os meios para que a contenda austrosérvia não transbordasse em um conflito internacional". ${ }^{36}$ Embora considerando improváveis tais desdobramentos, ele não excluiu esta possibilidade e, na linha das declarações ao embaixador austríaco no dia 5 de julho, reafirmou sua aceitação de uma guerra contra a Rússia em uma conversa particular com o industrial Krupp von Bohlen und Halbach: "The Kaiser told him he would declare war at once Russia mobilized. This time people would

\footnotetext{
${ }^{31}$ Tagebucheintrag des Generalobersten Plessen do 5 de julho 1914. repr. in Geiss I, p. 87.

${ }^{32}$ Depoimento por escrito [para a Comissão de Inquérito do Parlamento Alemão] do capitão marítimo Zenker sobre sua conversa com o Kaiser no dia 5 de julho 1914, 8.11.1914. Repr. in: Geiss I, p. 87-8.

${ }^{33} \mathrm{DD}$, vol 1, pp XV - XVIII. Geiss I, pp. 86-90.

${ }^{34}$ Mombauer, A. Helmuth von Moltke. Afflerbach, H. Falkenhayn. Ainda no dia 19 de julho, quando a Áustria-Hungria já tinha decidido inequivocamente em prol da guerra, Waldersee duvidava das preparações militares dos austríacos. DD Nr. 74 Der Oberquartiermeister im Großen Generalstabe an den Staatssekretär des Auswärtigen (Privatbrief). Hopman, A.; Das ereignisreiche Leben eines "Wilhelminers". Tagebücher, Briefe, Aufzeichnungen 1901 bis 1920. Ed. por Michael Epkenhans. Viena (Oldenbourg) 2004, p. 385.

${ }^{35}$ Falkenhayn an Moltke, 5.7.1917. Repr. in Geiss I, p. 86.

${ }^{36}$ Relatório de Bethmann Hollweg sobre conversa com Guilherme II no dia 5 de julho. Repr. in: Geiss I, p. 85.
} 
see that he would not change his mind ["wird nicht umfallen"]. The Kaiser's emphatic and repeated asseveration that this time nobody would be able to reproach him with irresolution had produced an almost comic effect." ${ }^{37}$

Nestes dois dias do início de julho, o Kaiser não se limitou a endossar decisões da liderança política alemã, como nos conflitos que antecederam a Crise de Julho, mas tomou, autocraticamente, a iniciativa e empurrou a Áustria em direção a uma guerra com a Sérvia. E esta guerra que tinha todo potencial para provocar um conflito europeu mais amplo. Foi um golpe de mestre de Guilherme, o abrupto.

\section{No alto mar: "Localização" da guerra, pressões sobre a Áustria e o ultimato..$^{38}$}

$\mathrm{Na}$ manhã do dia 6 de julho, Guilherme partiu para o porto de Kiel a fim de, um dia depois, iniciar seu cruzeiro anual nas águas norueguesas, acompanhando os exercícios da sua frota naval. Desta vez, entretanto, ele não foi tanto ao norte como nos anos anteriores, mas ficou perto de Balholm, a uma distância de 22 horas de navio do porto alemão de Kiel. Ele estava inseguro se realmente deveria fazer esta viagem frente à crise nos Bálcãs, mas seu chanceler insistiu muito, para criar a sensação de normalidade e/ou para se livrar da interferência de seu imprevisível imperador. A partir do momento de seu embarque no Hohenzollern, até sua volta no dia 27 de julho, Guilherme ficou um pouco afastado e em segundo plano. Foi a liderança política (Bethmann Hollweg, Jagow, Zimmermann, Stumm), também na ausência de uma boa parte da cúpula militar, que comandava a política exterior do Reich.

Guilherme era informado a bordo do Hohenzollern sobre o andamento do conflito, principalmente sobre os passos austríacos, porém isso muito parcialmente e com a supressão intencional de notícias que poderiam colocar em dúvida a estratégia alemã de pressionar por uma guerra austrosérvia e sua aposta na neutralidade das outras potências europeias. Especialmente os telegramas do embaixador alemão em Londres, o conde Karl

\footnotetext{
${ }^{37}$ Revelations by an ex-Director of Krupp's. Dr. Mühlon's Memorandum and his letter to Herr von Bethmann-Hollweg. New York (George H. Doran Co.), sem data. O memorando de Mühlon foi publicado inicialmente no Berliner Tageblatt do dia 21 de março de 1918.

38“"Localização". O termo, usado pela diplomacia, em alemão é "Lokalisierung", o que significa circunscrever, limitar, restringir o conflito austro-sérvio à região balcânica e a uma guerra somente entre a Áustria e a Sérvia, sem interferência de nenhuma outra potência.
} 
Max von Lichnowsky, que enfaticamente alertavam contra a "ilusão da localização" do conflito e de uma neutralidade britânica, foram censurados pelo AA. ${ }^{39}$

Por que o chanceler queria o Imperador longe de Berlim e afastado da possibilidade de exercer influência imediata sobre a política alemã? Parece que Bethmann Hollweg não somente teria sido forçado, na reunião com Guilherme no dia 5 de julho, a aceitar a "carta branca" como fait accompli, mas que ele também pegou carona no belicismo do Kaiser para implementar a sua própria política de extrair vantagens estratégicas para a Alemanha e a Tríplice Aliança através uma guerra entre a Sérvia e a Áustria.

Bethmann Hollweg, um personagem ainda avaliado muito controversamente pela historiografia, certamente não foi um representante da ala belicista no governo guilhermino. Ele se empenhou por um compromisso com a Grã-Bretanha e rejeitou a ideia de uma guerra de prevenção contra a Rússia e a França. Ele não queria uma guerra europeia em julho de 1914, porém sua política de (altíssimo) "risco calculado" brandiu esta possibilidade para chantagear a Rússia (e as outras potências da Tríplice Entente) a aceitar uma possível derrota da Sérvia pelo exército austríaco. (JARAUSCH, 1969, p,48-76); (HILLGRUBER,1986, p.34-57); (HILLGRUBER,1966, p.332-357) Ele brincou com fogo, como escreveu Mark Hewitson. O sucesso de tal estratégia dependia da não-intervenção russa ao lado da Sérvia.

Consequentemente, o empenho pela "localização" (regionalização) do conflito virou peça-chave da política alemã na Crise de Julho. ${ }^{40}$ A diplomacia alemã se esforçou por convencer as potências da Triple Entente do suposto caráter local do conflito. Porém, por trás dos discursos

\footnotetext{
${ }^{39}$ Por exemplo, no dia 27 de julho, quando Lichnowsky indicou mais uma vez que, em caso de uma guerra russo-alemã, a Grã-Bretanha iria se posicionar contra a Alemanha, Jagow perguntou ao chanceler: "O telegrama [de Lichnowsky] deve ser apresentado a Sua Majestade? Dificilmente poderia ser ocultado dela?"- como os telegramas anteriores. DD Nr. 283. Der Reichskanzler an den Kaiser, 28. Juli 1914, anotação marginal de Jagow. Para as outras alterações das mensagens de Lichnowsky ver, por exemplo: DD Nr. 29. Der Botschafter in Wien an das Auswärtige Amt, 10. Juli 1914. DD Nr. 157. Der Botschafter in London an das Auswärtige Amt, 24. Juli 1914.

${ }^{40}$ DD Nr. 36. Der Staatssekretär des Auswärtigen an den Botschafter in London, 12. Juli 1914. Nr. 72. Der Staatssekretär des Auswärtigen an den Botschafter in London (Privatbrief), 19. Juli 1914. DD Nr. 100. Der Reichskanzler an die Botschafter in Petersburg, Paris und London, 21. und 22. Juli 1914. Embora Bethmann Hollweg também professasse o mantra do despreparo da Rússia, ele mesmo assim exprimiu, às vezes, dúvidas e estava ciente de que, em 1914, a Rússia estaria firmemente contraposta, em seus interesses balcânicos, à Áustria-Hungria. DD Nr. 3. Der Reichskanzler an den Botschafter in London, 16. Juni 1914.
} 
diplomáticos aparecia a ameaça alemã de transformar a briga balcânica em guerra europeia pelo apoio prometido à Áustria, caso as potências não aceitassem o pressuposto da regionalização. Esta política de "localização" foi, assim, tanto uma esperança, i.e uma crença no despreparo da Rússia e da França, quanto uma estratégia diplomática proativa para isolar o conflito balcânico. Mas, ao mesmo tempo, representava uma ameaça velada de guerra contra estes dois países.

A convicção de que os países da Entente desistiriam de um envolvimento em uma guerra verdadeira pela causa de um país balcânico formou a base desta política de alto risco da Alemanha. Este mantra foi recitado incontáveis vezes pela liderança alemã na Crise de Julho: a Rússia ainda não estaria pronta com seu programa de rearmamento, e a França e a Grã-Bretanha seriam pacíficas, por causa dos seus problemas e prioridades na política doméstica e se empenhariam por frear um possível belicismo russo. ${ }^{41} \mathrm{~A}$ ameaça de uma intervenção armada, ademais, seria somente um blefe por parte da Rússia. ${ }^{42}$ Como colocou o subsecretário Zimmermann: "Blefar é um dos requisitos mais apreciados da política russa, e o russo gosta de ameaçar com a espada; porém, no momento decisivo, prefere não usá-la especialmente pela causa de outros. " $"$ Esta estratégia do "risco calculado" se baseava, é óbvio, em um conjunto de pressuposições equivocadas, resultado de desejos ilusórios e de uma profunda incompreensão das complexidades da política dos países envolvidos. Richard Lebow demonstrou com clareza como a estrutura hierarquizada e, ao mesmo tempo, fragmentada da liderança política da Alemanha e a péssima qualidade profissional do serviço diplomático e de seus embaixadores, contribuíram para estas "deficiências cognitivas" e para as "patologias no processo decisório". (LEBOW,1981, p. 119-147)

O que complicou também a política alemã do blefe com a guerra foi o fato de que somente seria possível ameaçar, em função do sistema

\footnotetext{
${ }^{41} \mathrm{~A}$ entrada no diário do Theodor Wolff, editor-chefe do Berliner Tageblatt, do dia 25.7., relatando uma conversa com von Jagow, bem resume tais cálculos alemães. Theodor Wolff. Tagebucheintrag über Gespräche mit Jagow und Stumm vom 25.7.1914. Repr. in: Krumeich, Gerd: Juli 1914. Eine Bilanz. Paderborn (Ferdinand Schöningh Verlag) 2014, p. 284-5.

${ }^{42}$ Para as muitas advertências de que a Rússia não iria tolerar a violação da soberania sérvia, ver: Krumeich. Juli 1914, pp. 98-106.

${ }^{43} \mathrm{DD}$, Anexo IV. Berichte, Telegramme und Telephongespräche der Bayerischen Gesandtschaft in Berlin. Nr. 2, Der Geschäftsträger in Berlin an den Vorsitzenden im Ministerrat, 18.7.1914.
} 
de alianças, da "carta branca" a ser concedida à Áustria-Hungria e do plano Schlieffen, com uma guerra plena europeia, incluindo a invasão da Bélgica. Esta guerra certamente teria provocado uma reação britânica a favor da Entente. Ademais, sendo acompanhada pelo raciocínio da inevitabilidade de uma "guerra final entre os eslavos e os germanos", esta estratégia abriu uma forte expectativa de aceitação de tal guerra e da interpretação da postura russa como um teste para sua belicosidade ou pacificidade per se.( HILLGRUBER, 1986, p.50) "Esta ação contra a Sérvia pode levar a uma guerra mundial", raciocinou Bethmann Hollweg já no início de julho. Mas "talvez o velho Kaiser [Francisco José] não decida a favor de uma guerra. Se esta guerra vem do leste, [i.e], se nós entrarmos no campo da batalha para apoiar a Áustria, [...] neste caso, temos a chance de vencer esta guerra. Se a guerra não acontece, se o Czar não a quiser ou se a debilitada França pressionar por paz, ainda temos a perspectiva de dividir a Entente com esta ação. " (RIEZLER,2008, p.182-4) (4 $^{44}$

Uma guerra austro-sérvia imediata fazia parte do cálculo estratégico de Bethmann, bem como das recomendações que o Kaiser havia dado aos austríacos em Potsdam no dia 5 de julho. Porém, a demora austríaca logo começou a ameaçar os desígnios estratégicos da Alemanha, como lamentou Bethmann: "Parece que a Áustria necessita de um tempo excessivamente longo para se mobilizar. Isto é muito perigoso. Um rápido fait accompli [ataque austríaco] e depois gentilezas para com a Entente. Assim aguentaremos o choque. " (RIEZLER,2008, p.184-5) A Alemanha, principalmente o Imperador e seu embaixador em Viena, von Tschirschky, ficaram irritados com o lento processo decisório de seu aliado, e logo começaram a pressionar a Áustria para proceder ao ataque. ${ }^{46}$ Já no dia 6 de julho, o embaixador Tschirschky transmitiu, "com toda ênfase", a mensagem de Guilherme para o Ministro das Relações Exteriores da Áustria, ressaltando que a Alemanha esperava uma ação contra a Sérvia e que ela não compreenderia se deixasse passar esta oportunidade. Negociações com a Sérvia, a Alemanha consideraria como uma manifestação de fraqueza, que poderia trazer consequências para a posição futura da Áustria na Tríplice

\footnotetext{
${ }^{44}$ Anotações dos dias 7 e 8 de julho 1914.

${ }^{45}$ Anotação do dia 11.7.1914.

${ }^{46}$ DD Nr. 29. Der Botschafter in Wien an das Auswärtige Amt, 10. Juli 1914.
} 
Aliança. ${ }^{47}$

$\mathrm{E}$ as pressões continuavam muito vigorosamente, até o ponto em que a Áustria se sentiu coagida. " ${ }^{48}$ "Eu acredito", escreveu o embaixador Conde Szögyény no dia 12 de julho, "que precisa ser esclarecido que os grupos decisivos [massgebliche Kreise] na Alemanha, e não por último sua própria Majestade Guilherme II, diria eu, quase nos empurra para uma ação bélica contra a Sérvia. "49 Além da pressão sobre a Áustria, o Kaiser, enquanto navegava em alto mar, participou também ativamente da construção de alianças nos Bálcãs, respectivamente negociando posturas neutras para salvaguardar politicamente a guerra austro-sérvia. ${ }^{50}$

Entretanto, o processo decisório da Áustria-Hungria era árduo e demorado. Na reunião do Conselho Ministerial no dia 7 de julho, decidiu-se por uma guerra em princípio, mas Tisza conseguiu impedir sua implementação imediata com a insistência em infligir primeiramente uma derrota diplomática à Sérvia. ${ }^{51}$ Surgiu o plano de encaminhar um ultimato com exigências inaceitáveis. Iniciou-se então a busca pelas "exigências, que impossibilitariam a aceitação pela Sérvia. " 52 No dia 19 de julho, o Conselho Ministerial decidiu sobre o procedimento da entrega do ultimato e o prazo de 48 horas para que a Sérvia o aceitasse..$^{53}$ No dia 21 de julho, o Imperador Francisco José sancionou o ultimato, que finalmente foi entregue pelo embaixador Giesl ao governo sérvio no dia 23 de julho às 18.00 horas. O ultimato significou, depois da "carta branca", a segunda etapa na escalada entre o assassinato do arquiduque e uma guerra europeia. No dia 25 de julho, Viena recebeu a resposta sérvia ao ultimato e a rejeitou, como tinha sido planejado. Retirou seu embaixador, rompeu as relações diplomáticas e ordenou a mobilização parcial do seu exército.

O governo alemão sabia antecipadamente do teor "inaceitável"

\footnotetext{
${ }^{47}$ ÖD I, 10. Schreiben des Grafen Berchtold an den Grafen Tisza, 8. Juli 1914. Ver também as notas marginais de Guilherme no telegrama do embaixador Tschirschky do dia 10 de julho: DD Nr. 29. Der Botschafter in Wien an das Auswärtige Amt, 10. Juli 1914.

${ }^{48}$ ÖD I, 13. Graf Szögyény an Grafen Berchtold, 9. Juli 1914.

${ }^{49}$ ÖD I, 15. Graf Szögyény an Grafen Berchtold, 12. Juli 1914.

${ }^{50}$ DD Nr. 26. Der Kaiser an den Kaiser von Österreich, 9. Juli 1914. DD Nr. 141. Der Gesandte im kaiserlichen Gefolge an das Auswärtige Amt, 24. Juli 1914.

${ }^{51}$ ÖD I, 8. Ministerrat für gemeinsame Angelegenheiten, 7. Juli 1914.

${ }^{52}$ DD Nr. 29. Der Botschafter in Wien an das Auswärtige Amt, 10. Juli 1914.

${ }^{53}$ ÖD I, 26. Minsterrat für gemeinsame Angelegenheiten, 19. Juli 1914.
} 
do ultimato ou até mesmo deu assistência à sua formulação? Um dia após a reunião ministerial em Viena, a Alemanha já havia sido informada do plano austríaco de empurrar a Sérvia para uma guerra através de um ultimato inaceitável pela sua soberania. No entanto, não deu assistência concreta para sua formulação. ${ }^{54}$ Cada dia, a Alemanha recebia novos detalhes sobre o teor do ultimato, mas o texto mesmo somente foi lhe enviado no dia 22 de julho. Este envio aconteceu antes da sua entrega à Sérvia, dando à Alemanha ainda tempo para reagir. ${ }^{55}$ Porém, ela não freou a Áustria no último momento, mas em vez disto, endossou as exigências austríacas inaceitáveis.

Enquanto tudo isto ocorria, Guilherme estava navegando nas águas norueguesas. A partir da entrega do ultimato austríaco, ficou crescentemente nervoso e xingava a todos, principalmente nas suas notas marginais: os austríacos, por causa da demora; seu próprio chanceler, com o qual estava ressentido por não haver sido informado suficientemente; "os eslavos", bem como a Rússia e a Grã-Bretanha, quando sentiu que estas não iriam engolir tão facilmente o ultimato e a guerra austro-sérvia. ${ }^{56}$ Ele se manifestou expressamente belicista, principalmente contra a Rússia, sem contudo desistir de interpretar a postura russa como blefe. ${ }^{57}$ Ele reforçou a conduta austríaca dura e até sugeriu o aniquilamento da Sérvia, bem como a conquista austríaca de partes do seu território: “A Áustria deveria chegar a uma posição preponderante nos Bálcãs, frente à Rússia e às custas dos Estados menores. "58

Diante da escalada das tensões com a entrega do ultimato e a mobilização do exército sérvio, o Kaiser não conseguiu ficar quieto e afastado

\footnotetext{
${ }^{54}$ DD Nr. 19. Der Botschafter in Wien an das Auswärtige Amt, 8. Juli 1914.

${ }^{55}$ Tschirschky an Jagow, 11.7.1914, repr. em Geiss I, p. 147-8. DD Nr. 49. Der Botschafter in Wien an den Reichskanzler, 15. Juli 1914. DD Nr. 77. Der Staatssekretär des Auswärtigen an den Botschafter in Wien, 19. Juli 1914. DD Nr. 83. Der Staatssekretär des Auswärtigen an den Botschafter in Wien, 20. Juli 1914. DD Nr. 106. Der Botschafter in Wien an den Reichskanzler, 22. Juli 1914.

${ }^{56}$ DD Nr. 120. Der Botschafter in Petersburg an den Reichskanzler, 23. Juli 1914. DD Nr. 117. Der Botschafter in Konstantinopel an das Auswärtige Amt, 23. Juli 1914. DD Nr. 121. Der Staatssekretär des Auswärtigen an den Kaiser, 23. Juli 1914. DD Nr. 155. Der Botschafter in Wien an das Auswärtige Amt, 24. Juli 1914. DD Nr. 149. Der Botschafter in Konstantinopel an das Auswärtige Amt, 24. Juli 1914. DD Nr. 157. Der Botschafter in London an das Auswärtige Amt, 25. Juli 1914.

${ }^{57}$ DD Nr. 120. Der Botschafter in Petersburg an den Reichskanzler, 23. Juli 1914.

${ }^{58}$ Anotações marginais em: DD Nr. 120. Der Botschafter in Petersburg an den Reichskanzler, 23. Juli 1914. DD Nr. 155. Der Botschafter in Wien an das Auswärtige Amt, 24. Juli 1914 e DD Nr. 159. Der Gesandte in Belgrad an das Auswärtige Amt, 25. Juli 1914.
} 
de Berlim. No dia 24 de julho, ele assumiu o comando da frota marítima alemã, que ainda estava se exercitando no mar nórdico, ordenou seu agrupamento e, finalmente, contra os desesperados protestos de Bethmann Hollweg, comandou seu retorno para o porto de Kiel. ${ }^{59}$ No dia 26, ele decidiu, também contra os conselhos expressos de seu chanceler, encerrar antecipadamente seu cruzeiro e regressar a Berlim, onde chegou um dia mais tarde. Nesta viagem de volta, perturbado e alternando rapidamente entre a paz e a possibilidade iminente de uma guerra, já começara a planejar o confronto com a Rússia. Ele ordenou ao Comandante da Frota, Almirante von Ingenohl, a atacar os portos russos de Reval e Libau. Ademais, entregou uma parte da frota e a responsabilidade pela segurança no Mar Báltico ocidental, inclusive seu bloqueio, ao comandante do porto de Kiel, temendo "um segundo Porto Arthur", desta vez pelos russos contra a Alemanha. ${ }^{60}$ Tais ordens foram, obviamente, ignoradas. (VON MÜLLER, 1959, p.34); (RÖHL,2014, p.1038); (HOPMAN,2004, p.400) Porém, de outro lado, alternando para a expectativa de paz, ele planejou de se retirar, juntamente com sua esposa, depois de uma breve estada em Potsdam, para seu retiro provincial, o castelo Wilhelmshöhe, perto da cidade de Kassel. (RÖHL, 2014, p.1046)

\section{"Halt in Belgrad!" - A reviravolta pela paz de Guilherme II}

Guilherme desembarcou no porto de Kiel na manhã do dia 27 de julho, e continuou a viagem por trem, munido de novos relatórios. $\mathrm{Na}$ pequena estação de Wildpark, perto de Berlim, foi recebido por uma comitiva composta por muitos dos seus conselheiros, agora retornados das suas férias. Recebeu mais documentos da correspondência diplomática e um briefing verbal de Bethmann Hollweg. Estes documentos, cuja maioria relatava a situação russa, eram preocupantes e indicavam os primeiros indícios da mobilização do exército russo. ${ }^{61}$ Bethmann Hollweg, ainda apostando na política da

\footnotetext{
${ }^{59}$ DD Nr. 221. Der Reichskanzler an den Kaiser, 26. Juli 1914. DD Nr. 175. Der Admiralstab an den Staatssekretär des Auswärtigen, 25. Juli 1914. DD Nr. 182. Der Reichskanzler an der Kaiser, 25. Juli 1914. DD Nr. 231. Der Kaiser an das Auswärtige Amt, 26. Juli 1914.

${ }^{60}$ Anotações marginais no: DD Nr. 221. Der Reichskanzler an den Kaiser, 26. Juli 1914. Röhl, J. Wie Deutschland den Krieg plante. Süddeutsche Zeitung, 2.3.2014: https://www.sueddeutsche.de/politik/kaiser-wilhelm-weltkrieg-1.1903963

${ }^{61}$ DD Nr. 194. Der Botschafter in Petersburg an das Auswärtige Amt, 26. Juli 1914. DD Nr. 216. Der Botschafter in Petersburg an das Auswärtige Amt, 26. Juli 1914. DD Nr. 291 Der
} 
regionalização, mas temendo uma reação brusca por parte do Imperador, mandou mensagens tranquilizadoras que minimizavam a escalação do conflito. Destacou que Áustria não começaria com uma ação militar antes do dia 12 de agosto e que a Grã-Bretanha, a França e a Itália desejavam a paz. A Rússia não se estaria mobilizando mas pretendia negociar com a Áustria. ${ }^{62}$

Contudo, o Kaiser sentiu que a aposta alemã na regionalização do conflito e na não-interferência russa começou a erodir seriamente. Chegando em Wildpark, com muita fúria ele se dirigiu ao seu chanceler: "Como tudo isto pôde acontecer?" O chanceler ofereceu sua renúncia, que não foi aceita. (PRINCE VON BÜLOW, 1931, p. 161) ${ }^{63}$ Nos dias seguintes, porém, o Kaiser continuou reclamando em público da "incompetência" do seu chanceler, que reiteradamente apontou, não admitindo sua própria contribuição, como culpado pelo desastre de uma guerra iminente. (TIRPITZ,1920, p. 237)

No restante do dia 27 de julho, ele ainda não deixava entrever uma clara reviravolta de sua postura. Mas Albertini acredita que, já na reunião com Bethmann mais cedo, ele deve ter manifestado seu desejo de uma solução pacífica do conflito austro-sérvio.(ALBERTINI,1953, v. 2, p. 467) ${ }^{64}$ Neste dia, porém, Guilherme ainda rejeitou a proposta feita por Chelius, no sentido de escrever uma carta pessoal ao imperador russo, e participou de preparações diplomáticas (embora rotineiras) para uma eventual guerra, tentando reter a Itália a seu lado através de generosas compensações territoriais por parte da Áustria. ${ }^{65}$

Finalmente, no dia 28 de julho, bem cedo, seu medo de uma guerra se manifestou com todo ímpeto. Logo no início do dia, ainda antes de

\footnotetext{
Militärbevollmächtige am russischen Hofe an den Kaiser, 28. Juli 1914.

${ }^{62}$ DD Nr. 245. Der Reichskanzler an den Kaiser, 27. Juli 1914. O Kaiser recebeu este telegrama na sua viagem de trem entre Kiel e Berlim.

63. Albertini sugere que tal desabafo de Guilherme poderia ter acontecido dias mais tarde, no dia 29 de julho, quando Bethmann "tinha colapsado" completamente. (ALBERTINI, 1953,V2, p. 437).

$64 \mathrm{O}$ fato de Bethmann ter encaminhado o oficio do embaixador alemão em Londres (DD Nr. 258) para Viena, ainda antes da manifestação do Kaiser por escrito na sua "Halt in Belgrad" proposta, corrobora tal acontecimento.

${ }^{65}$ DD Nr. 229. Der Botschafter in Petersburg an das Auswärtige Amt, 26. Juli 1914. DD Nr. 233. Entwurf eines nicht abgesandten Telegramms des Kaisers an den Zaren, 26. Juli 1914. DD Nr. 244. Der Botschafter in Rom an den Reichskanzler, 27. Juli 1914. DD Nr. 267. Der Staatssekretär des Auswärtigen an den Botschafter in Wien, 27. Juli 1914.
} 
partir para sua cavalgada habitual com seu ajudante-geral, General Plessen, Guilherme lera o último despacho do embaixador alemão em Londres, no qual se relatava o pleno apoio do governo britânico à resposta sérvia ao ultimato austríaco e se expressava a convicção desse governo de que um ataque à Sérvia levaria a uma resposta militar por parte da Rússia. ${ }^{66}$ Já na cavalgada junto com Plessen, Guilherme anunciou sua reviravolta para a paz e contra qualquer guerra. Ele reiterou que a Grã-Bretanha sinalizava que a Sérvia teria respondido satisfatoriamente ao ultimato austríaco e com isto, não existiriam mais razões para uma guerra. Foi Plessen, que, nesta conversa, deu a ele a ideia de "Parar em Belgrado" ("Halt in Belgrad”), observando que a Áustria precisaria pelo menos de uma garantia para a implementação das promessas sérvias.

Depois de voltar da cavalgada, Guilherme finalmente tomou conhecimento da resposta sérvia ao ultimato austríaco, que Bethmann e Jagow haviam escondido dele por um dia. Evidentemente, os dois queriam que a Áustria declarasse guerra antes de o Kaiser ter conhecimento da resposta sérvia. Ao ler o documento sérvio, ele exclamou, numa nota marginal: "Uma realização brilhante num prazo de somente 48 horas. Isto é mais do que se esperava! Um grande sucesso moral para Viena: mas, com isto, é eliminada qualquer razão para uma guerra [...]! [Com base nesta resposta] eu nunca teria decretado a mobilização! "ำ Mas Guilherme foi mais longe, certamente não confiando que suas notas marginais fossem compreendidas como uma ordem. Ele se sentou à mesa e redigiu pessoalmente, pela primeira vez em toda a Crise de Julho, um ofício ao Secretário das Relações Exteriores, no qual ordenou uma reviravolta radical na política alemã, renunciando indiretamente a "carta branca" dada à Áustria-Hungria no dia 5 de julho.

Neste oficio, Guilherme aponta que a resposta sérvia, humilhante e capituladora, teria satisfeito os desejos austríacos, deixando somente alguns pontos a serem resolvidos por negociação. Com isto, abandonou a posição categórica e radical de três dias atrás, de que o ultimato

\footnotetext{
${ }^{66}$ DD Nr. 258. Der Botschafter in London an das Auswärtige Amt, 27. Juli 1914. Este despacho da embaixada alemã em Londres foi o primeiro, depois de algum tempo, a ser encaminhado pelo AA a Guilherme, na íntegra e não alterado, como no caso anterior..

${ }^{67}$ Note marginal (do dia 28.7.) ao DD Nr. 271. Antwortnote der serbischen Regierung auf das österreichish-ungarische Ultimatum, 27. Juli 1914. Ver também sua nota marginal em: Nr. 337 Der Militärbevollmächtigte am russischen Hofe an das Auswärtige Amt, 29. Juli 1914.
} 
deveria ser cumprido à risca. ${ }^{68}$ Ele desistiu também de seu posicionamento anterior, de que a Áustria deveria estabelecer sua hegemonia nos Bálcãs através da ocupação territorial de uma parte da Sérvia. ${ }^{69}$ Ademais, ele agora rejeitava in toto a ideia de uma guerra austro-sérvia e aconselhou, incorporando a sugestão de von Plessen, somente a ocupação temporária de Belgrado para forçar a implementação das promessas sérvias. Por último, deu ordem a Jagow para intervir neste sentido junto a Viena.

Assim como aconteceu no dia 5 de julho, o Kaiser repentinamente realizou uma reviravolta abrupta, desta vez pela paz. O que provocou esta mudança na sua postura? Muitos autores sugerem que foi a leitura do ofício do embaixador alemão em Londres, que teria sinalizado uma parcialidade britânica ao lado da Rússia e da França. Significa que o profundo medo de Guilherme do poderio da Grã-Bretanha teria provocado esta mudança repentina, mas que ele não queria evitar uma guerra per se, isto é, ele ainda teria aceitado uma guerra contra a Rússia. ${ }^{70}$ Alguns indícios, no entanto, contradizem esta interpretação. O oficio de Londres em questão, ao contrário dos despachos anteriores de Lichnowsky ${ }^{71}$, que não haviam sido levados ao conhecimento do Kaiser, pouco mostra uma clara postura britânica. Só menciona que "não poderíamos contar com a simpatia e apoio inglês". Um apoio britânico, todavia, em contrário a sua neutralidade, não havia sido antecipado por quem quer que seja. Inversamente, acerca da reação russa, o documento se expressou com muita clareza. Ademais, tudo indica que, a esta altura, ainda se contava com a neutralidade da Grã-Bretanha. (RÖHL,2014, p.1052);(KRUMEICH,2014);(TIRPITZ,1920,p.238)Parece que as informações, deduzidas a partir da viagem do Príncipe Heinrich à Inglaterra, e de seu relato pessoal de uma conversa com o Rei George V da Inglaterra, fez com que Guilherme acreditasse na não-intervenção daquele país. Ele contava com a neutralidade britânica, mas, mesmo assim, não queria uma guerra germanorussa. "Seria uma loucura completa", ele declarou, "se estourasse uma guerra

\footnotetext{
${ }^{68}$ Nota marginal no: DD Nr. 154. Der Botschafter in Paris an das Auswärtige Amt, 24. Juli 1914.

${ }^{69}$ Nota marginal no: DD Nr. 155. Der Botschafter in Wien an das Auswärtige Amt, 24. Juli 1914.

${ }^{70}$ Fischer, Röhl e Gutsche insistem nesta interpretação.

${ }^{71}$ Por exemplo DD Nr. 180. Der Botschafter in London an das Auswärtige Amt, 25. Juli 1914.
} 
generalizada [por causa do conflito austro-sérvio]." Ele insistiu, em frente a todos seus conselheiros militares reunidos no "Conselho da Coroa", em prosseguir com sua intervenção junto a Viena. Foi decidido levá-la a cabo antes de tomar outras decisões. ${ }^{72}$

Quando redigiu seu despacho para Jagow, na manhã do dia 28, Guilherme não parecia ter muita pressa. Não esperava, portanto, uma ação militar imediata por parte da Áustria. Tudo indica que ele, ao contrário de Bethmann Hollweg e Jagow, não sabia do plano austríaco de declarar guerra neste dia, ou no dia seguinte, e confiava nas informações de que somente em 12 de agosto a Áustria-Hungria iria iniciar a guerra. ${ }^{73}$ Ele enviou por mensageiro seu despacho ao AA e depois sugeriu uma entrega pessoal a Viena por um enviado especial. Pensava que assim teria resolvido a situação e que o perigo de uma guerra houvesse desaparecido, arquitetando já novos planos de se retirar para Wilhelmshöhe, longe de Berlim. (RÖHL,2014, p. 1055; HOPMAN,2004, p.402) Ainda na tarde do dia 29, ele presumiu ter mudado o rumo da política austríaca. Quando Chelius, o plenipotenciário militar alemão na corte russa, constatou num ofício que nenhuma potência teria conseguido tirar a Áustria do caminho da guerra, ele exclamou, duas vezes sublinhando: "Pelo contrário - nós conseguimos!"74

Neste momento, entretanto, iniciou-se uma jogada diplomática por parte da liderança política alemã, que bem pode ser considerada como conspiração para esvaziar a iniciativa do Kaiser e torná-la sem efeito. Primeiro, Bethmann Hollweg demorou tanto a enviar o ofício, agora por telégrafo, alegando que não havia mais conexão ferroviária entre Berlim e Viena, que este somente poderia ser considerado no dia seguinte, isto é, depois da declaração de guerra da Áustria contra a Sérvia. Quando o ofício chegou na embaixada alemã em Viena, o embaixador Tschirschky deu continuidade às delongas, até

\footnotetext{
${ }^{72}$ Relatório do Almirante Tirpitz do "Kronrat" (29.7.), in: Geiss II, pp. 274-5. DD Nr. 456. Protokol der Sitzung des k. preußischen Staatsministeriums am 30. Juli 1914.( ALBERTINI, 1953,2, p. 496)

${ }^{73}$ Se Guilherme sabia da iminente declaração de guerra pela Áustria permanece duvidoso. O telegrama de Tschirschky, informando sobre tais planos (DD 257), chegou no AA no dia 27 de julho e, segundo as anotações, foi levado ao conhecimento do Kaiser. O próprio Guilherme, porém, nada comentou a respeito, nem fez referência a ele nas suas manifestações subsequentes. Uma boa parte da literatura assume o desconhecimento desta decisão por Guilherme..( ALBERTINI, 1953,2, p. 470)

${ }^{74} \mathrm{DD}$ Nr. 344. Der Militärbevollmächtigte am russischen Hofe an das Auswärtige Amt, 29. Juli 1914 (nota marginal do Kaiser).
} 
o ponto em que o próprio Bethmann Hollweg perdeu a paciência. ${ }^{75}$

Ainda mais importante, Bethmann Hollweg e Jagow manipularam intencionalmente o despacho do Kaiser de tal forma que seu espírito e sua intenção (de desautorizar uma guerra austro-sérvia) foram neutralizados. Eles omitiram que o Kaiser havia aceito a resposta sérvia e que ele não via mais nenhuma razão para uma guerra. Insinuaram que a Áustria deveria abandonar a sua postura "totalmente intransigente" por razões táticas, isto é, por causa da opinião pública europeia, que reagiria contra ela. Se a Áustria continuasse a rejeitar qualquer negociação, o "mau cheiro [Odium], por ter culpa de uma guerra mundial, recairia sobre ela, também aos olhos do povo alemão. Nesta base, não seria possível iniciar e conduzir uma guerra bem sucedida em três frentes". Por último, fizeram questão “de não dar a impressão de que queríamos deter a Áustria. "76 Ademais, na comunicação deste oficio por Tschirschky ao Ministro das Relações Exteriores da Áustria-Hungria, as intenções do Kaiser deveriam ter sido ainda mais atenuadas. A resposta verbal do Ministro Berchthold, de que "[ele] agradecia a sugestão, mas [...] não poderia dar uma resposta imediata", fala por si. $^{77}$ Finalmente, Bethmann Hollweg desmontou qualquer impacto da iniciativa guilhermina sobre as decisões austríacas, reafirmando explicitamente que a Alemanha cumpriria lealmente suas obrigações de aliança com a Áustria. ${ }^{78}$

A intervenção do Kaiser pela paz e sua proposta do "Halt in Belgrad" poderia ter mudado o rumo da escalada para uma guerra europeia? A literatura diverge neste assunto. Alguns historiadores negam sua viabilidade, argumentando que a Rússia teria reagido a qualquer violação da soberania sérvia. ${ }^{79}$ Existem, porém, indícios de que, contrariamente às declarações do Ministro das Relações Exteriores da Rússia no início da Crise de Julho e no momento da publicação do ultimato, ele talvez tivesse aceitado uma ocupação

\footnotetext{
${ }^{75}$ DD Nr. 377. Der Reichskanzler an den Botschafter in Wien, 29. Juli 1914. DD Nr. 385 Der Reichskanzler an den Botschafter in Wien, 30. Juli 1914.

${ }^{76}$ DD Nr. 323. Der Reichskanzler an den Botschafter in Wien, 28. Juli 1914. Obviamente, este despacho nunca foi mostrado ao Kaiser. Ainda mais, Bethmann Hollweg continuou enviando despachos que explicitamente contradiziam a aceitação da resposta sérvia ao ultimato por Guilherme. DD Nr. 279. Der Reichskanzler an den Botschafter in London, 28. Juli 1914.

${ }^{77}$ DD Nr. 388. Der Botschafter in Wien an das Auswärtige Amt, 30. Juli 1914.

${ }^{78}$ DD Nr. 396. Der Reichskanzler an den Botschafter in Wien, 30. Juli 1914.

${ }^{79}$ Ver Röhl. Wilhelm II, p. 1057.
} 
temporária de Belgrado para evitar uma guerra europeia. ${ }^{80}$ Ainda mais, o embaixador italiano em Viena havia feito uma proposta semelhante, desconhecida por Guilherme. E tudo indica que o Ministro britânico, Edward Grey, também teria aceitado uma ocupação temporária de Belgrado, seguida por negociações. ${ }^{81}$ Assim, Luigi Albertini, que certamente não é conhecido pela sua simpatia pela política alemã, elogia a iniciativa guilhermina: "The idea of a Halt in Belgrade, as this proposal is generally called by historians, was quite ingenious. Wilhelm was, after all, more quickwitted, intelligent, and perspicacious than his Ministers and put forward an expedient which held the balance well between the two sides." John Röhl, outro crítico feroz de Guilherme, também acredita que a implementação da proposta teria, talvez, evitado a catástrofe que estava prestes a acontecer. " (ALBERTINI, 1953, v2, p.469); (RÖHL, 2014, p.1054); (MEYER-ARNDT, 2006, p.145)

No mesmo dia da reviravolta do Kaiser, a Áustria declarou guerra contra a Sérvia, e um dia depois, seus navios de guerra no rio Danúbio bombardearam a cidade de Belgrado. Esta declaração de guerra significava a terceira etapa de escalada do conflito. Mas, com isto, a ideia do "Halt in Belgrad" ainda não havia morrido completamente e o Kaiser ansiosamente esperava uma manifestação por parte da Áustria.

Por que a liderança política alemã (Bethmann Hollweg e Jagow) optou por minar a iniciativa imperial pela paz? É muito provável que Bethmann Hollweg, no dia 28 de julho, ainda acreditasse na viabilidade de sua política de regionalização, apostando que a declaração austríaca de não ter “ambições territoriais" na Sérvia, isto é, de não ocupar permanentemente território sérvio, ainda fosse suficiente para fazer a Rússia aceitar uma guerra austro-sérvia.(HILLGRUBER,1986,p.51) Ele considerava a reviravolta do Kaiser como prematura, e não quis admitir, até o dia 29 de julho, o fracasso de sua política de "risco calculado". Ele ainda defendia seu "diplomatic

\footnotetext{
${ }^{80}$ DD Nr. 460. Der Botschafter in London an das Auswärtigen Amt, 31. Juli 1914, citando um telegrama do Ministro Grey ao seu embaixador em Moscou. DD Nr. 395. Der Reichskanzler an den Botschafter in Wien, 30. Juli 1914.

${ }^{81}$ DD Nr. 368. Der Botschafter in London an das Auswärtige Amt, 29. Juli 1914. DD Nr. 439. Der Botschafter in London an das Auswärtige Amt, 30. Juli 1914. Ainda mais, no dia 30 de julho, o Principe Heinrich recebeu um telegrama do Rei George V, no qual informava sua concordância com a ocupação de Belgrado e as regiões adjacentes como garantia das reivindicações austríacas, se todos os outros países cessassem seus preparativos para a guerra. DD Nr. 452. Der König von England an Prinz Heinrich von Preußen, 30. Juli 1914.
} 
masterpiece", como colocou seu antecessor Bülow. ${ }^{82}$ Por esta razão, ele também rejeitava as propostas de mediação (quatro até este momento) feitas pela Grã-Bretanha.

De outro lado, ele já havia percebido o abismo no qual a política alemã estava operando, e iniciou uma estratégia diplomática paralela que permitiria travar a guerra contra a Rússia e a França "nas melhores condições possíveis". Era uma estratégia dupla: ainda não descartar toda esperança de paz mas, mesmo assim, se preparar para a guerra. Assegurar a neutralidade britânica e o apoio para tal guerra pela sociedade alemã, especialmente pela Social Democracia, eram peças chaves desta estratégia. Para conseguir isto, a Rússia deveria aparecer, em todo caso, como culpada pela eclosão das hostilidades, e a Alemanha e a Áustria como pacíficas e vítimas. Aceitar, como fachada ou não, as propostas de mediação, tornou-se elemento crucial desta política. Ao transmitir a proposta guilhermina pela paz, embora adulterada, ele deu a orientação de que se tratava somente de um "modo que permitiria [...] desmontar a propaganda por uma Grande Sérvia, sem desencadear uma guerra mundial, e, se esta se mostrar inevitável, melhorar as condições para travá-la." 83 Os telegramas pessoais, que Bethmann Hollweg sugeriu a Guilherme enviar a seu primo Nicolau II, Czar da Rússia, conhecidos como parte dos famosos “telegramas Willy-Nicky", foram inspirados por esta estratégia: "Tal telegrama", ele escreveu ao Kaiser no dia 28 de julho, "no caso em que aconteça a guerra, deixará aparecer, com muita clareza, a culpa russa." 84

A própria reviravolta de Bethmann Hollweg um dia mais tarde, quando percebeu o fracasso total da política de regionalização e enviou em desespero seus dois "Weltbrandtelegramme" (expressando o medo de um “incêndio mundial”) a Viena, revela também esta estratégia dupla: "Se Viena [...] recusa qualquer concessão, especialmente se rejeita a última proposta [britânica] de Grey, não será mais possível atribuir a culpa da conflagração europeia, que está irrompendo, à Rússia. [... Se Viena] rejeita tudo, mostra que

\footnotetext{
${ }^{82}$ Prince von Bülow. Memoirs, 1909-1919, p. 150. Alguns autores, entre eles Meyer-Arndt, argumentam que, embora Bethmann Hollweg tivesse assinado os despachos para Viena, von Jagow e von Stumm do AA eram mais instrumentais na derrubada da iniciativa do Kaiser. Meyer-Arndt, pp. 146-9.

${ }^{83}$ DD Nr. 323. Der Reichskanzler an den Botschafter in Wien, 28. Juli 1914.

${ }^{84}$ DD Nr. 308. Der Reichskanzler an den Kaiser, 28. Juli 1914.
} 
ela queria, de qualquer jeito, uma guerra, que nos envolverá, enquanto a Rússia ficará sem culpa. Isto cria para nós, frente à nossa própria nação, uma situação plenamente insustentável. ${ }^{85}$

A iniciativa do Kaiser pela paz do dia 28 de julho não surtiu efeito em função do boicote cínico e maquiavelista por parte de sua própria liderança política ou por ter sido atingido pela mobilização geral russa precipitada? Parcialmente sim.

Mas por outro lado, faltava força e determinação a Guilherme. Ele tinha o destino europeu nas suas mãos, e assim o percebeu. Ele não queria mais uma guerra austro-sérvia por causa do medo de uma conflagração europeia, chegou a esboçar uma fórmula pela paz, mas fracassou na implementação. Ao contrário de suas frequentes demonstrações de poderes autocráticos, seja no dia 5 de julho, quando quase sozinho direcionou a política alemã para o caminho da confrontação, ou no dia 26 de julho, quando, contra os protestos do seu chanceler, ordenou a volta da frota de guerra e decidiu o seu próprio retorno, ou, ainda mais, no dia $1^{\circ}$ de agosto, quando ordenou, contra a resistência de todo comando militar, uma parada no avanço do exército alemão na fronteira com Luxemburgo - desta vez mostrou timidez e falta de coragem. Uma intervenção rápida e direta, junto ao Imperador austríaco, ameaçando a retirada do apoio, teria surtido um efeito imediato. Mas, certamente, não queria fazer isto, uma vez que tinha dado sua "palavra de honra" ao Imperador. Perguntou, repetidas vezes, ao seu chanceler, se seu ofício realmente tinha sido encaminhado e ficou esperando, servil mas crescentemente irritado, a resposta austríaca. ${ }^{86}$ E, sendo altamente influenciável: em vez de insistir ele facilmente cedeu às pressões. Como o Ministro (Prussiano) da Guerra, Falkenhayn, colocou no seu diário: "[O Kaiser] está proferindo discursos confusos, que somente mostram uma coisa

\footnotetext{
${ }^{85} \mathrm{DD}$ Nr. 441. Der Reichskanzler an den Botschafter in Wien, 30. Juli 1914. Bethmann Hollweg cancelou este segundo Weltbrandtelegramm duas horas depois do envio. As duas explicações, que Bethmann Hollweg deu para este cancelamento podem ser interpretadas no sentido de que agora tinha aceitado a guerra contra a Rússia e não queria mais deter a Áustria. DD Nr. 450. Der Reichskanzler an den Botschafter in Wien, 30. Juli 1914. DD. Nr. 451. Entwurf eines nicht angesandten Telegramms des Reichkanzlers an den Botschafter in Wien, 30. Juli 1914. DD Nr. 464. Der Reichskanzler an den Botschafter in Wien, 31. Juli 1914. DD Nr. 437. Der Kaiser an den Kaiser von Österreich, 30. Juli 1914.

${ }^{86}$ Relatório do Almirante Tirpitz do "Kronrat" (29.7.), in: Geiss II, pp. 274-5. Notas marginais em: Nr. 367 Der Botschafter in Paris an das Auswärtige Amt, 29. Juli 1914 e em: Nr. 368 Der Botschafter in London an das Auswärtige Amt, 29. Juli 1914
} 
com clareza: que ele agora não quer mais a guerra e que está determinado a abandonar a Áustria por isto. Eu chamei a atenção dele para o fato de que não tinha mais controle sobre este assunto." (AFLERBACH,1994, p. 154)

\section{Conclusões}

Já a partir do dia 24 de julho, a Rússia se manifestara com muita clareza que não iria aceitar uma violação da soberania sérvia e reagiria com uma guerra se a Áustria tentasse "engolir" este país. No dia seguinte, iniciou-se o "Período Preparatório para a Guerra" e, no dia 28 de julho, foi anunciada a mobilização parcial de seu exército.

A Alemanha reagiu com uma advertência de não dar prosseguimento a uma mobilização geral, pois esta significaria verdadeiramente uma guerra. No mesmo dia (29 de julho), o Conselho Ministerial do governo russo votou a favor da mobilização geral, mas a intervenção do Czar, impressionado pelos telegramas do Guilherme, retardou sua implementação por um dia. No dia 30 de julho, no período da tarde, as ordens para a mobilização geral russa foram dadas, e ao meio dia do dia 31, Berlim recebeu as respectivas informações. A Alemanha declarou o "Estado de Perigo de Guerra Iminente" e emitiu um ultimato à Rússia, de "cessar qualquer preparativo de guerra contra nós e a Áustria-Hungria" no prazo de 12 horas. Se não o fizesse, a Alemanha, por sua vez, mobilizaria o seu exército, o que significaria inevitavelmente a guerra.

A Rússia não recuou e, no dia $1^{\circ}$ de agosto, às 17 horas, Guilherme assinou a ordem para a mobilização geral, para ter efeito no dia seguinte. Às 19 horas, o embaixador alemão, Pourtalès, com lágrimas nos olhos, entregou a declaração alemã de guerra ao governo russo. Vinte e quatro horas depois, a Alemanha e a França mobilizavam os seus exércitos. Nesta altura, a diplomacia alemã ainda se empenhou, porém sem muita esperança, pela neutralidade britânica no conflito, mas a invasão da Bélgica no dia 4 de agosto pelo exército alemão deu um dos motivos e a justificativa para a GrãBretanha, por sua vez, declarar guerra à Alemanha.

No mesmo dia, a Condessa Mechthild Lichnowsky, esposa do embaixador alemão em Londres, derrubou o retrato do Kaiser da escrivaninha 
do seu marido, e gritou: "Este é o suíno que cometeu o crime!" Ela tinha razão? Em grande medida sim. Mostramos como, em dois momentos chaves da Crise de Julho, a postura do Kaiser deu uma contribuição fundamental para colocar a Alemanha no caminho da confrontação armada. A sua responsabilidade era tanto de ação (dia 5 de julho) quanto de omissão (dias 28 a 30 de julho). No dia 5 de julho, espontaneamente, e em um surto de megalomania autocrática, ele sancionou a guerra austro-sérvia e, em seguida, pressionou o seu aliado austríaco para logo pegar em armas. Dominou a sua marcialidade, seu militarismo e seu autoritarismo, bem como o lado impulsivo e a imprevisibilidade do seu caráter. Neste momento, ele tinha todas as opções e poderia ter continuado com a postura de cautela, que caracterizava a sua política nas crises balcânicas anteriores. Ele não queria a "grande guerra", não era um defensor da "guerra de prevenção" contra a Rússia, mas assumiu o risco, abafando seu medo com o estupido mantra de que a Rússia ainda não estava pronta para tal guerra.

Quando esta guerra se revelou como possibilidade real, ele ficou atemorizado e apresentou seu "plano pela paz". Neste segundo momento, porém, quando tinha ainda o destino de paz ou guerra nas suas mãos, fracassou, e mostrou o outro lado da sua personalidade: a insegurança, a falta de coragem e liderança e sua susceptibilidade a pressões, manipulações e influências por terceiros. Sua intervenção foi tímida e sem a determinação necessária. Ele não recorreu aos amplos instrumentos de poder disponíveis a ele para frear o caminho para a catástrofe. Volátil e inseguro, ele rapidamente cedeu e se entregou às manipulações do seu chanceler e ao boicote austríaco de sua proposta. No final, ele se rendeu ao cálculo da dinâmica das necessidades militares, defendido pelos militares.

O papel trágico de Guilherme na Crise de Julho reflete tanto a sua personalidade problemática, alternando entre megalomania e fraqueza, quanto o sistema de seu regime político semi-autocrático, que lhe concedera tantos poderes e que o colocara em uma posição a cujas exigências não conseguia corresponder. Neste sentido, o indivíduo e sua personalidade têm importância e devem ser levados em conta para se abrir uma janela pela melhor compreensão do caminho alemão para a guerra.

Ademais, o lado sistêmico do drama guilhermino pode ser 
atenuado ainda mais por uma perspectiva comparativa, isto é pelo fato de que, nos tempos mais recentes, plenas democracias, jovens e mais consolidadas, também não conseguiram barrar determinadas personagens da tomada do poder, que, mesmo com a legitimidade do voto popular, demonstraram estar igualmente inaptas para o exercício de cargos de responsabilidade e que conseguiram mergulhar seus países em um abismo de crise e tristeza.

\section{Referências}

AFFLERBACH, H.. Falkenhayn. Politisches Denken und Handeln im Kaiserreich, Munique: 1994.

ALBERTINI, L. The Origins of the War of 1914, 3 vols., London: 1953.

BRUNS, F. ; KARENBERG, A..Vom Neurastheniker zum Bipolaren: Kaiser Wilhelm II. im Spiegel psychiatrischer Diagnosen des 19. und 20. Jahrhunderts. Fortschr Neurol Psychiatr., 29.8.2019.

CLARK, C. The Sleepwalkers: How Europe Went to War in 1914. Londres: 2012.

CONRAD, F. Aus meiner Dienstzeit, Vol. III. Viena:1922.

FISCHER, F. Griff nach der Weltmacht. Die Kriegszielpolitik des Kaiserlichen Deutschlands. Düsseldorf: 1961.

GUTSCHE, W. Wilhelm II., der letzte Kaiser des Deutschen Reiches: Eine Biographie. Berlim: 1991

HAMILTON, R. F.; HOLGER, H. H. Decisions for War, 1914-1917. Nova Iorque: 2005.

HILLGRUBER, A. Deutschlands Rolle in der Vorgeschichte der beiden Weltkriege. Göttingen: 1986.

HILLGRUBER, A. Riezlers Theorie des kalkulierten Risikos und Bethmann Hollwegs Politische Konzeption in der Julikrise 1914. In: Historische Zeitschrift, vol. 202, Munique: 1966, p. 332-357.

HOPMAN, A.; Das ereignisreiche Leben eines "Wilhelminers". Tagebücher, Briefe, Aufzeichnungen 1901 bis 1920. Ed. por Michael Epkenhans. Viena: 2004.

JARAUSCH, K. H. The Illusion of Limited War: Chancellor Bethmann Hollweg's Calculated Risk, July 1914, in: Central European History, 2/1(1969), pp. $48-76$. 
KANTOROWICZ. Gutachten zur Kriegsschuldfrage, Frankfurt am Main: 1967.

KRUMEICH, G. Juli 1914. Eine Bilanz. Paderborn: 2014.

LEBOW, R.N.. Between Peace and War. The Nature of International Crisis. Baltimore e Londres: 1981.

LICHNOWSKY, K. M. My Mission to London, 1912-1914. Nova Iorque e Londres: 1918

MALINOWSKY, S. Vom König zum Führer. Sozialer Niedergang und politische Radikalisierung im deutschen Adel zwischen Kaiserreich und NSStaat. Berlim (Akademieverlag): 2003.

MARTEL, G. The Month that Changed the World. July 1914. Oxford :2014.

MCMEEKIN, S. Juli 1914. Der Countdown in den Krieg. Berlim: 2014.

MEYER-ARNDT, L. Die Julikrise 1914. Wie Deutschland in den Ersten Weltkrieg stolperte. Colónia, Viena: 2006.

MOMBAUER, A. Helmuth von Moltke and the Origins of the First World War. Cambridge: 2001.

OTTE, T. July Crisis. The World's Descent into War: Summer 1914. Cambridge: 2014.

PRINCE VON BÜLOW. Memoirs, 1909-1919. Londres \& Nova Iorque: 1931.

RIEZLER, K. Tagebücher, Aufsätze, Dokumente. Ed. por Erdmann, K.D. Göttingen: 2008.

RÖHL, J. Kaiser Wilhelm II. Eine Studie über Cäsarenwahnsinn, Munique: 1989.

RÖHL, J. Wilhelm II: Into the Abyss of War and Exile. Cambridge: 2014.

TIRPITZ (Admiral) A. Von. Erinnerungen. Leipzig: 1920.

URBACH, K.; Hitlers heimliche Helfer. Der Adel im Dienst der Macht, Darmstadt: 2016.

URBACH, K.. Nützliche Idioten. Die Hohenzollern und Hitler. In: Thomas Biskup, Truc Vu Minh, Jürgen Luh (ed.): Preußendämmerung: Die Abdankung der Hohenzollern und das Ende Preußens. Heidelberg: arthistoricum.net, 2019.

VON MÜLLER. Regierte der Kaiser?: Kriegstagebücher, Aufzeichnungen und Briefe des Chefs des Marine-Kabinetts Admiral Georg Alexander von Müller, 1914-1918. Ed. por Walter Görlitz. Göttingen: 1959. 
Coleções de fontes primárias:

BD - British Documents on the Origins of the War, 1898-1914. Vol. XI: The Outbreak of War: Foreign Office Documents. Ed. G.P. Gooch \& Harold Temperley. London 1926.

DD - Die Deutschen Dokumente zum Kriegsausbruch 1914. Kautsky, K. (ed.); Vollständige Sammlung der von Karl Kautsky zusammengestellten amtlichen Aktenstücke mit einigen Ergänzungen. Im Auftrag des Auswärtigen Amtes nach gemeinsamer Durchsicht mit Karl Kautsky hrsg. von Graf Max Montgelas und Walter Schücking. 4 vols., Charlottenburg 1919.

GEISS I e II - Geiss, Imanuel (ed.), Julikrise und Kriegsausbruch 1914. Eine Dokumentensammlung, 2 vols. Hannover 1963/64.

GP - Die Große Politik der europäischen Kabinette 1871-1914. Sammlung der Diplomatischen Akten des Auswärtigen Amtes. Im Auftrag des Auswärtigen Amts, Berlin 1922-1927.

ÖD - Die Österreichisch-Ungarischen Dokumente zum Kriegsausbruch. Hrsg. vom Staatsamt für Äußeres in Wien (Berlin: National-Verlag), 1923. 